\title{
Identification of Social and Occupational Risk Factors Associated with CKDu (Chronic Kidney Disease of Unknown Etiology) Patients Living in an Agricultural Community in Kebithigollewa, Sri Lanka
}

\author{
Chamodika Lowe ${ }^{1, *}$, and Nishantha Kumarasinghe ${ }^{2}$ \\ ${ }^{1}$ Department of Biomedical Science, Faculty of Science and Engineering, University of Wolverhampton, Wolverhampton, United Kingdom \\ ${ }^{2}$ Department of Anatomy, Faculty of Medicine, General Sir John Kotelawala Defence University, Rathmalana, Sri Lanka
}

*Corresponding author: Chamodika Lowe, Department of Biomedical Science, Faculty of Science and Engineering, University of Wolverhampton, Wolverhampton, United Kingdom, E-mail: chamodilowe@yahoo.com

Received: 26 Jul, 2021 | Accepted: 17 Sep, 2021 | Published: 25 Sep, 2021

Citation: Lowe C, Kumarasinghe N (2021) Identification of Social and Occupational Risk Factors Associated with CKDu (Chronic Kidney Disease of Unknown Etiology) Patients Living in an Agricultural Community in Kebithigollewa, Sri Lanka. Int J Nephrol Kidney Fail 7(4): dx.doi. org/10.16966/2380-5498.217

Copyright: (c) 2021 Lowe C, et al. This is an open-access article distributed under the terms of the Creative Commons Attribution License, which permits unrestricted use, distribution, and reproduction in any medium, provided the original author and source are credited.

\begin{abstract}
Aim: To identify the social and occupational risk factors associated with CKDu (Chronic Kidney Disease of unknown etiology) patients living in an agricultural community in Kebithigollewa, Sri Lanka.

Methods: A three months community based cross sectional study was done involving 30 CKDu diagnosed patients who were attending the CKDu Western Ayurvedic Integrated Clinic at Kebithigollewa, North Central Province (NCP), Sri Lanka and 30 controls were taken from the same region. Socioeconomic and socio-demographic data was collected from the participants with the use of an interview administered questionnaire. Heights and weights were the anthropometric data measured for the study. Blood samples were collected as biochemical data which was later analysed using an automated blood analyser. Data collected was computerized and analysed using software Graphpad Prism 8 and SPSS version 20.

Results: All the participants of the research were active residents living in the NCP since birth. $83.34 \%$ of the CKDu affected individuals were from the $4^{\text {th }}$ to $7^{\text {th }}$ decade of life and $70 \%$ of them were males. $86.66 \%$ of the affected population carried out agricultural practices as their main source of income with chena and paddy cultivation being the common practice followed. $96.66 \%$ of the affected were from low income families who earned 0-20000 LKR (Sri Lankan Rupee) per month. 40\% of the affected have had only up to five years of school education. 63.33\% of the CKDu patients were overweight. A significant correlation of 0.642218 was shown by Cramer's V square test between Number of working hours/day and serum creatinine, indicating a strong association, but did not have a significant nominal logistic regression.
\end{abstract}

Conclusion: Serum creatinine was high in farmers and laborers indicating that occupation impacts CKDu occurrence and progression. It was also high in the age group 31-50 yrs showing a significant relationship with serum creatinine which indicates the social impact on CKDu occurrence. A statistically significance of $\mathrm{P}<0.05$ was shown by number of working hours and BMI (Body Mass Index).

Keywords: Agrochemicals; Agricultural activities; Chronic Kidney Disease (CKD); CKD of Unknown Etiology (CKDu); Heavy metals; National research programme for CKDu ; North Central Province (NCP); Sri Lanka; Tubulointerstitial nephritis; World Health Organization (WHO).

Abbreviations: BEN: Balkan Endemic Nephropathy; CKD: Chronic Kidney Disease; CKD-EPI: Chronic Kidney Disease Epidemiology Collaboration; CKDu: Chronic Kidney Disease of Unkown Etiology; E-GFR: Estimated Glomerular Filtration Rate; FN1: Fibronectin-1; KDQ: Kidney Disease Questionnaire; KDQOL: Kidney Disease Quality of Life; KLK1: Kallikrein-1; KIM1: Kidney Injury Molecule-1; MDRD: Modification of Diet in Renal Disease; MEN: Mesoamerican Nephropathy; NCP: North Central Province; NGAL: Neutrophil Gelatinase-Associated Lipocalin; NSAIDs: NonSteroidal Anti-Inflammatory Drugs; WHO: World Health Organization

\section{Introduction}

Early in the 1990s an unknown form of chronic kidney disease (CKD) was found in North Central Province (NCP) of Sri Lanka. Individuals suffering from the disease showed no signs of discomfort or early indicators of having a chronic kidney disease, hence it was known as chronic kidney disease of unknown etiology (CKDu). The disease has been prevalent among the paddy farmers of NCP and is beginning to spread to other districts of the country as well. It has become a major health problem in Sri Lanka affecting mostly the rural, socioeconomically poor agricultural communities of NCP. Various hypotheses have been brought up by both local and international researchers for the cause of CKDu. Cadmium and arsenic like heavy metals and agrochemicals like glyphosate that leads to environmental pollution, excessive fluorides coupled with water 
hardness, Hantavirus and leptospirosis like infections, genetic factors, and exposure to toxins of fungi and bacteria, and heat stress are some of those hypotheses [1].

According to studies, an approximate of $15-23 \%$ of the reported population in NCP is affected with CKDu and the numbers could be higher since majority of the CKDu cases are identified late in life. Hence, it's important to identify its risk factors, to lower and control the prevalence of new CKDu cases [2].

The main aim of the research was to identify the social and occupational risk factors associated with CKDu patients living in an agricultural community in Kebithigollawa, Sri Lanka. A cross sectional study was carried out to identify how a person's occupation, income, lifestyle and the social behaviours influence the cause and spread of CKDu.

\section{Background}

According to the definition by the committee of "National Research Programme for CKDu" launched by the World Health Organization (WHO) in 2008 in cooperation with the "Ministry of Healthcare and Nutrition", Chronic Kidney Disease is said to be of unknown origin if there's no history of past Diabetes Mellitus, sever/ chronic hypertension, glomerulonephritis/ urological diseases, snake bite; $<6.5 \%$ of normal HBA1C, $<160 / 100 \mathrm{mmHg}$ of untreated or $<140 / 90$ $\mathrm{mmHg}$ on antihypertensive medications (up to two). As suggested in previous studies, CKDu aetiology is probably multi-factorial including environmental factors and a vulnerable populations' possible genetic predisposition [3]. In Sri Lanka CKDu has been found as endemic to some areas such as Kebithigollawa, Padaviya, Nikawewa, Medirigiriya, Medawachchiya, Girandurukotte and Dehiattakandiya in NCP, where people's main source of income and occupation is agriculture. Hence, though the cause(s) of CKDu is yet to be known, it is highly evident and justifiable that chronic exposure and cumulative long-term effects of heavy metal has a predominantly positive role towards the spread of CKDu [4].

\section{CKD and CKDu}

CKD which is a globally prevailing health burden is estimated to have affected approximately 500 million of people worldwide out of which over $80 \%$ are considered to be suffering from CKDu and is living in low or middle income countries [5]. A kidney damage proven by abnormalities in kidney structure or function either with decreased GFR or without, for more than for a period of 3 months is defined as CKD. Unlike CKD, CKDu has no early indicators for the disease progression, CKD is recognized to be the result of long-term/ chronic diseases which includes hypertension, diabetic mellitus, vascular diseases, obstructive uropathy, tubulointerstitial diseases and primary or secondary glomerular diseases, or it can also be due to a congenital disease like polycystic kidney disease. With the use of KDOQI (National Kidney Disease Outcome Quality Initiative) criteria CKD has been staged into 5 grades depending on the disease severity as: Stage 1- if the renal damage is with a Glomerular Filtration Rate (GFR) normal or increased $\left(>90 \mathrm{~mL} / \mathrm{min} / 1.73 \mathrm{~m}^{2}\right)$, Stage 2 - if GFR mildly reduced $\left(60-89 \mathrm{~mL} / \mathrm{min} / 1.73 \mathrm{~m}^{2}\right)$, Stage 3 - if GFR moderately reduced (30-59 $\left.\mathrm{mL} / \mathrm{min} / 1.73 \mathrm{~m}^{2}\right)$, Stage 4 - if GFR severely reduced $(15-29 \mathrm{~mL} /$ $\mathrm{min} / 1.73 \mathrm{~m}^{2}$ ) and Stage 5- Kidney failure with GFR $<15 \mathrm{~mL} / \mathrm{min} / 1.73$ $\mathrm{m}^{2}$ or dialysis $[3,4]$.

\section{CKDu incidents across the world}

CKDu was first reported from Toyama, Japan in 1912 and was more prominent among postmenopausal women. Bone pain was a major symptom other than renal failure and muscle weakness, which made the disease to gain the name "Itai-Itai" disease meaning "ouch-ouch". Disease cause which was unknown was identified in 1968 as long-term exposure to Cadmium. CKDu was next reported in 1950s from rural villages that are along Danube River and is named as Balkan Endemic Nephropathy (BEN). Tubular acidosis, tubular proteinuria and impaired concentrating capacity are some features for BEN that affects both the genders equally. In 1993 Aristolochia species was identified as the causative agent of BEN [6]. In 2002 another case of CKDu

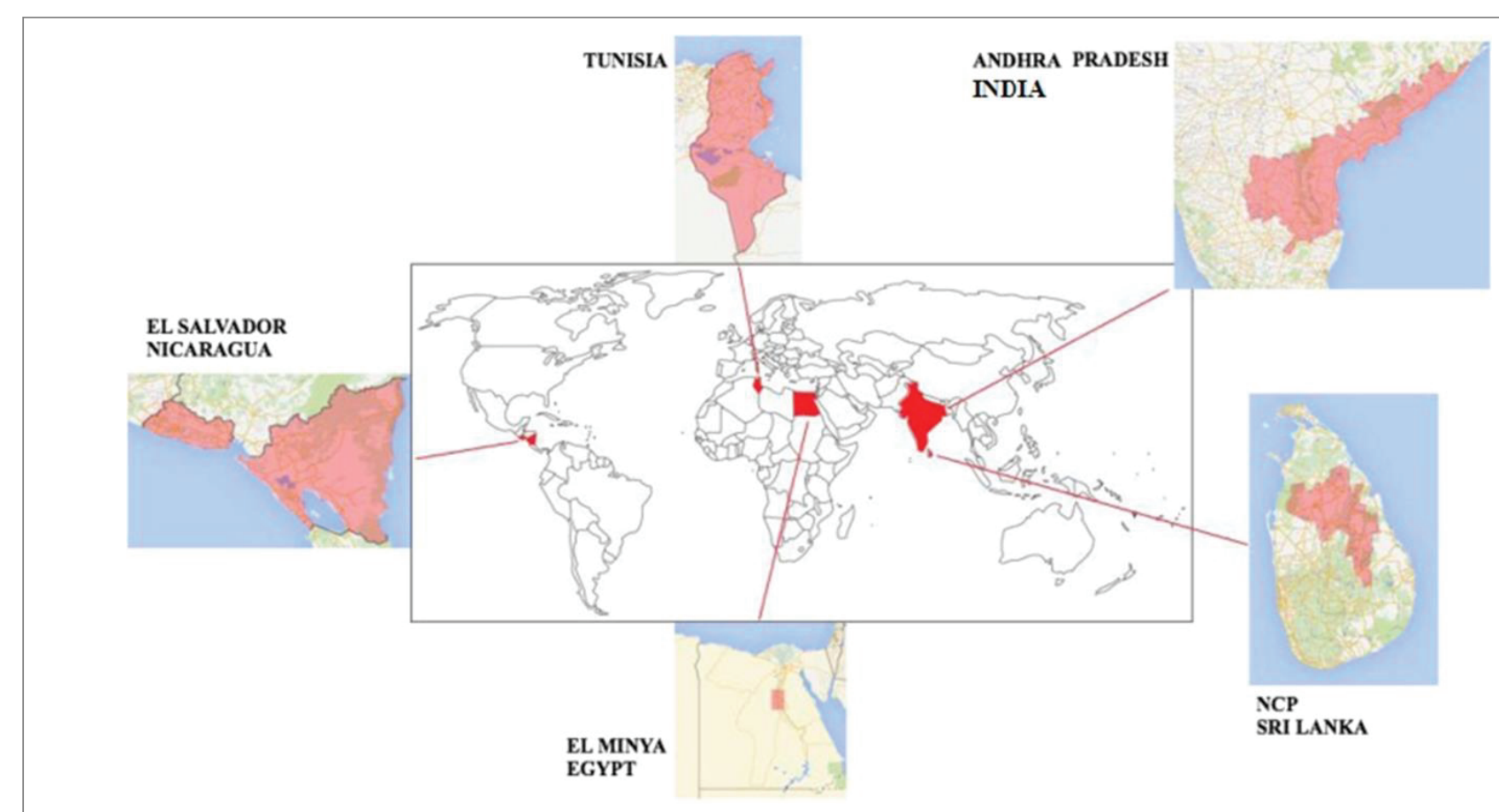

Figure 1: World map showing areas where CKDu is highly prevalent [6]. 
was reported from Central America among indigent agricultural communities laboring along the Pacific coast from Guatemala to Panama. It was common among male workers in low-altitude areas and sugarcane workers but was also seen among cotton, corn, shrimpfarm workers and mines and construction sites like industrial setting workers. It was named as Mesoamerican Nephropathy (MEN) and leukocyturia is one of its features but has no cause identified up to now. CKDu was reported in 1990s from rural areas with hot climate of India, specially, from Andhra Pradesh State and is named as Uddanam Nephropathy. It's is prominent among male famers of rice, coconuts and cashew nuts, while its causative factor/s remain unrecognized. Similarly, CKDu with yet an unknown cause was reported from Sri Lanka in 1990s mainly among male rice farmers in hot tropical NCP. CKDu has been reported from other parts of the world as well including Southern Egypt, Sudan, Veracruz State, Tierra Blanca and Mexico [7] (Figure 1).

\section{Suggested hypotheses for CKDu}

Though the aetiology of CKDu is not known, several hypotheses have been buildup on likely causative factors through researches. Drinking contaminated well water is one such factor where fertilizers used in agricultural activities tend to runoff through agricultural irrigation systems into nearby shallow wells leading to development of Hofmeister-type nephropathy which is assumed to be connected with $\mathrm{CKDu}$, in people drinking it. Minerals, metals and metalloids is another factor where depressed ratio of dissolved sodium to calcium by increased level of calcium causes fluoride toxicity in the presence of elevated fluorides leading to tubular cells damage [8]. This condition is further enhanced with the use of aluminum pans for cooking, as aluminum gets leached from those at acidic conditions like using tamarind in cooking, and bonds with fluoride making complexes that has the ability of releasing fluoride ions when entered the kidneys leading to toxicity [3]; another factor is agrochemicals. Excessive usage of these leads to alterations in both patterns of food-chains and water-cycle by contaminating crops and underground waters. Also its direct exposure leads to skin infections and organ damages. Arsenic and cadmium like heavy metals present as waste-products of agrochemicals and glyphosate causes renal damage which could be a causative of CKDu. Dehydration and exposure to extreme temperatures/ heat is another hypothesized causative. Working for many hours in hot temperatures causes body ion imbalance by excessive sodium loss through sweating leading to dehydration coupled with dysuria. This makes workers either to drink contaminated water from close by irrigation systems or to stay dehydrated, both of which causes renal damage by exerting oxidative stress on it and might lead to $\mathrm{CKDu}$ [9]. Regular and prolonged use of ayurvedic medications and Snake bites [10] have also been hypothesized as causes for CKDu. Another is Microbial toxins. Ochratoxin A is a fungal toxin produced by Aspergillus species at hot climates which could contaminate food leading to nephrotoxicity and carcinoma. Cyanobacteria produces toxins which could contaminate water leading to hepatic, skin and neurotoxicity in those who bath or drink from it. These toxins too could be probable causatives for CKDu. As CKDu can be seen among one's family members, its cause may also have a genetic involvement [3].

\section{Genetics}

Genetic factors might be important and may explain why this condition has been developed among several members of the same family. And the reason for its development in only a certain people but not in all, who are engaged in same at-risk occupation in a community, might be able to be explained by the genetic variants. Polymorphisms in "sodium-dependent dicarboxylate transporter member 3" which is also known as "Solute carrier family 13 member 3" (SLC13A3) and "voltage-gated potassium channel subfamily A member 10" (KCNA10) have been identified in initial studies as were associated with Sri Lankan nephropathy, which require additional studies for validation [7].

\section{Population at risk}

Those who work and live in hot environments, especially those engaged in paddy and chena farming and those with a poor socioeconomic status are mostly affected. It is also seen among individuals practicing other types of agricultural activities such as sugarcane cultivation at low altitudes and laborers working in hot environments. Men are affected more commonly than women and are in age range 20-50 yrs with 40-50 yrs of average presentation age. In Sri Lanka, mostly the rice paddy farmers living in rural areas are affected $[2,7]$.

\section{Clinical and histopathological characteristics}

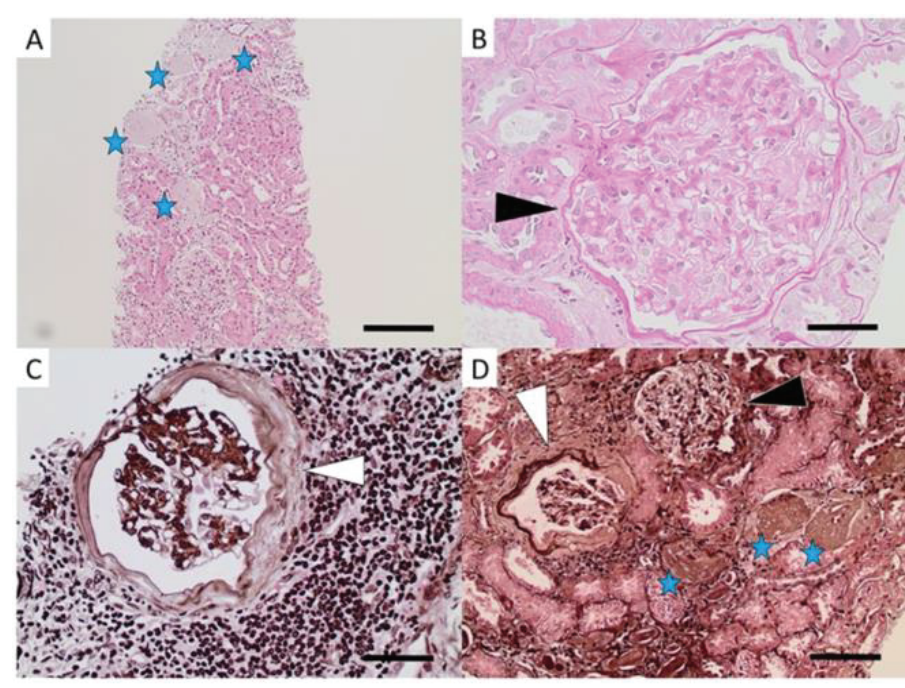

Global glomerulosclerosis

Glomerular hypertrophy

$>$ Signs of glomerular ischemia with thickening of Bowman's Capsule

A: hematoxylin-eosin stained, $b a r=200 \mu \mathrm{m}$. B: periodic acid Schiff stained, bar $=50 \mu \mathrm{m}$. C: periodic acid silver methenamine stained, bar $=50 \mu \mathrm{m}$.

D: periodic acid silver methenamine stained, bar $=100 \mu \mathrm{m}$.

Figure 2: Light microscopic images of Sri-Lankan CKDu Patients' glomerular pathology [11]. 


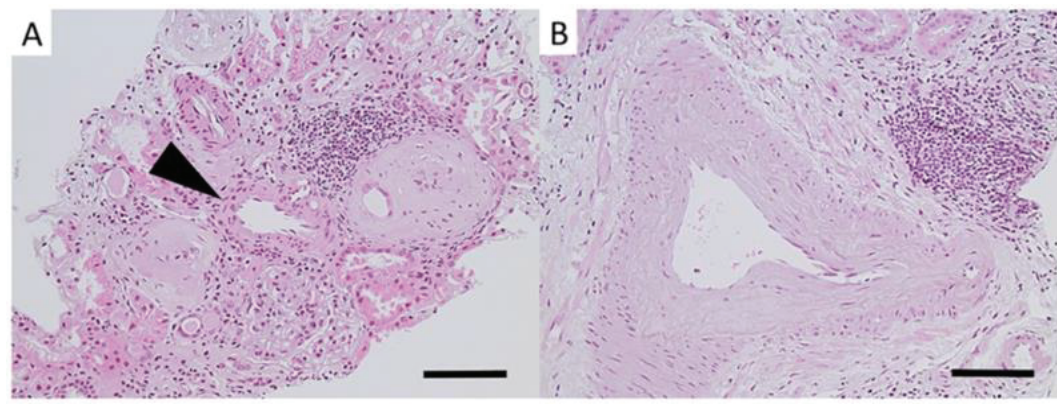

Arrow head in A: mild intimal fibrosis in arteries. Hematoxylin-eosin stained, bar $=100 \mu \mathrm{m}$.

B: moderate intimal fibrosis

Hematoxylin-eosin stained, bar $=100 \mu \mathrm{m}$.

Figure 3: Light microscopic images of Sri-Lankan CKDu Patients' vascular pathology [11].

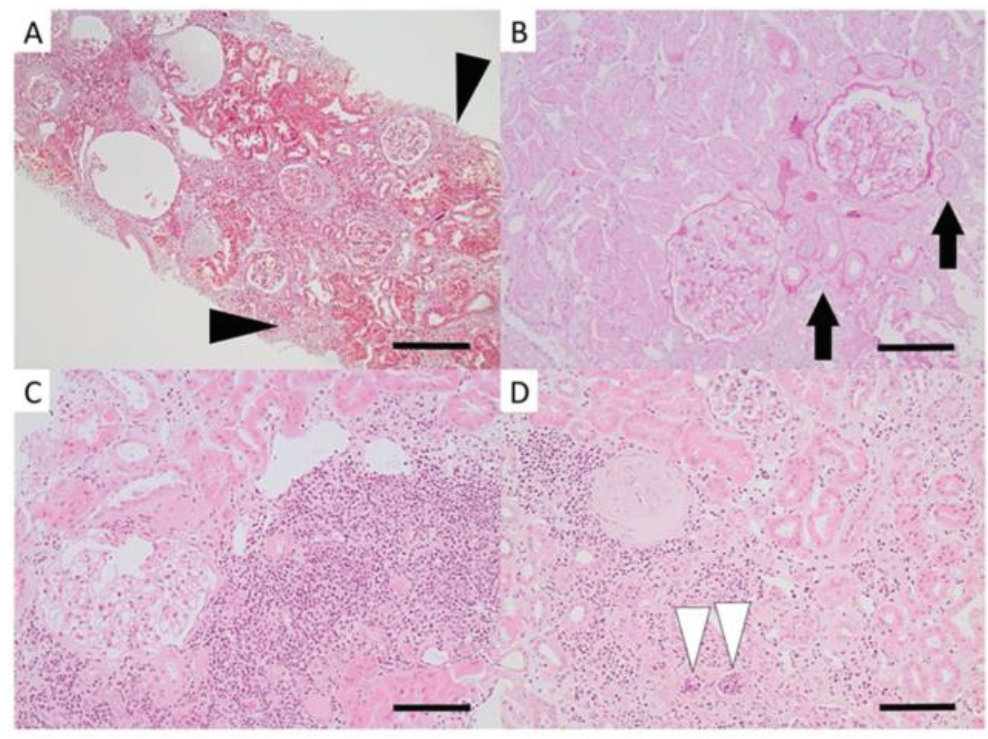

Mild to moderate

interstitial fibrosis

Mild tubular atrophy

Signs of pyelonephritis with interstitial inflammation and neutrophil granulocytes in tubules

A: Ladewig stained, bar $=200 \mu \mathrm{m}$.

B: periodic acid Schiff stainned, bar $=100 \mu \mathrm{m}$.

C: hematoxylin-eosin stained, bar $=100 \mu \mathrm{m}$.

D: hematoxylin-eosin stainned, bar $=100 \mu \mathrm{m}$.

Figure 4: Light microscopic images of Sri-Lankan CKDu patients' tubulointerstitial pathology [11].

Though hypertension and edema can be observed later in progression of the disease [8], joint pain, fatigue, fever and dysuria are observed commonly while headache, nausea and vomiting, muscle weakness and back pain are observed in some. An elevated level of serum creatinine is usually found in $\mathrm{CKDu}$ patients. Apart from that hyponatremia, hypokalemia, hypomagnesemia, no or low-grade proteinuria, frequent hyperuricemia are some abnormalities in their serum electrolytes. The size of kidneys is observed to be reduced on ultrasounds [7]. According to renal morphology, CKDu found in Sri Lanka is mostly said to be tubulointerstitial nephritis or rather a tubulointerstitial disease, though it might also show glomerulosclerosis and glomerular ischemia like glomerular lesions [11] (Figures 2,3 and 4). Commonly observed changes in renal histopathology of CKDu patients include glomerulosclerosis, tubular atropy and periglomerular, perivascular and focal-interstitial hypocellular fibrosis, showing that interstitium and proximal tubules are affected mainly [12].

\section{Diagnosis}

CKDu patients do not show any signs and symptoms of a kidney disease until its later stages leading to poor prognosis [13]. Commonly, the kidney disease is advanced to stage 3 or 4 with an eGFR $15-60 \mathrm{ml} /$ $\mathrm{min} / 1.73 \mathrm{~m}^{2}$ when diagnosed. Also yet it's unknown whether an early identification could help in reversing the disease [7].

Most common modes of testing: Renal biopsies being the gold standard for $\mathrm{CKDu}$ diagnosis, kidney ultrasound images show tissue scaring at end stages. Albumin and creatinine like biomarkers detection through blood and urine tests allows estimating GFR (eGFR) as a kidney function indicator [13]. Thus, eGFR and ratio of urinary albumin to creatinine is currently used for CKDu screening. Dipstick proteinuria is another commonly used test to detect CKDu but has low sensitivity. 1-microglobulin excretion in urine can also be measured for $\mathrm{CKDu}$ screening [8]. Microalbuminuria which is when albumin gets excreted in urine in the range $30-300 \mathrm{mg} / \mathrm{g}$ in women and $20-200$ $\mathrm{mg} / \mathrm{g}$ in men is used in screening for affected in CKD early stages [3].

Novel approaches: Studies are being carried out to find early CKDu detection methods as there's a probability in altering the disease progression and reducing disease complications if detected at early stages. Testing for biomarkers takes a priority among those as it has the ability to screen early, make treatments more effectively and give medical care a personalized approach. Accordingly, it is suggested that a combination of GSTM1 (Glutathione S transferase mu 1), GCLC (Glutamate 
Cysteine Ligase Catalytic subunit), IGFBP1 (Insulin-like Growth Factor Binding Protein 1) and KIM1 (Kidney Injury Molecule-1) genes panel could be used to early screen CKDu. Also, CKDu progression could be monitored with these genes added with IGFBP3, FN1 (Fibronectin-1) and KLK1 (Kallikrein-1) [14]. Ion-transporting protein, NGAL (Neutrophil Gelatinase-Associated Lipocalin) is a promising and a novel biomarker used in early detection of CKD and for monitoring the progression of kidney disease. Distal nephron produces NGAL in responding to kidney injury making it a marker of damage. Also since concentration of NGAL in serum is increased earlier than creatinine, it is a more powerful agent for CKD monitoring. Both NGAL and KIM1 are used as active-tubular-pathology markers [15]. Metabolomics and proteomics like "omics" technologies are used in detecting biomarkers of different CKDs through 2-Dimenetional gel electrophoresis like various methods [16].

Questionnaire-based approaches: Medical-research questionnaires are an important tool used for easily gathering information from large populations on individual perspectives. Modes of data collection using questionnaires could be personal, over the telephone, via postal service or through electronic media. Each method has both advantages and disadvantages. In general, the strength of the survey depends on the response rate and accuracy of the answers given but it's an efficient way to gather data [17]. In case of CKDu, taking of a detailed environmental and occupational history is important in identifying a history of use of pesticides, tobacco, herbal supplements and non-steroidal anti-inflammatory drugs (NSAIDs) like nephrotoxic substances, leptospirosis like infectious diseases or heavy laboring in hot environments [7] which could be easily done using questionnaires. Some examples of widely used questionnaires in CKD surveys include KDQOL (Kidney Disease Quality of Life) which was first formed in 1994 and its short-form version KDQOLTM-36 put forward in 2000 [18]; KDQ (Kidney Disease Questionnaire) and KTQ (Kidney Transplant Questionnaire).

\section{Prevention and treatment}

Prevention: Primary and secondary prevention methods include prevention of health risks associated with heat, lowering of exposure to sun and heat, increasing intake of safe water and other electrolytes to improve hydration, getting adequate rest, reducing of exposure to nephrotoxins, identification of the illness at early stages (subclinical and clinical) by conduction of medical surveillance in populations atrisk and conducting public awareness programs to educate the general public on preventive measures [7].

Clinical management: Clinical evaluation involves monitoring of eGFR reduces over a period of 6 months to one year using the results of serum creatinine combined with e-GFR equations such as CKD-EPI (Chronic Kidney Disease Epidemiology Collaboration) or MDRD. Biopsy and autopsy are the gold standard of testing as the histopathological features can be identified and analyzed to understand the significant impact of the disease. Other tests such as FBC, urine sample analysis, CT scans and ultrasound scans are widely used to understand the damage of the kidney disease and are widely being used across the world in determining the stage and effect of the kidney disease [7].

Treatment: Since there's no specific treatment modality, WHO have recommended drinking of safe drinkable water, changing agricultural practices and using of safety precautions at work, to reduce CKDu. Hypertension like accelerating factors can be controlled with medication [8]. Kidney transplantation or dialysis will be required for kidney diseases at end-stage [7]. But since this method of treatment is much costly and CKDu is often seen in low and middle income countries, often therapy of renal replacement is limited or unaffordable [11]. Therefore, alternative medicine is being used widely in Asian countries as a cost-effective and successful method to improve quality of life of CKDu patients. Accordingly, Sri Lankan traditional medicine has been identified by the action plan of WHO released in 2016 on CKDu in Sri Lanka as a cost effective method of management [13].

\section{CKDu in Sri Lanka}

$\mathrm{CKDu}$ in Sri-Lanka has been reported from Uva and NorthWestern provinces other than from NCP which reports the highest number of cases, and is reported to have started spreading into Southern and Central provinces as well [10]. It is mainly observed among the poor male population than the females in hot agricultural regions, which is mainly since most male farmers are actively working in the field whereas the females are more into helping them with other agricultural activities. As males are the main source of income of a family, and males in their productive working age are affected, their potential of earning is declined disturbing the economy of their families which indirectly affects the economy of the country. Dialysis treatment method is a limitedly available, expensive and an unaffordable modality for patients with low income which make them travel long distances searching for free dialysis providing government hospitals, bringing a burden for them and their families [19]. Recent studies have shown that CKDu has affected $15-23 \%$ of the NCP population, while a $227 \%$ annual rise of end-stage renal disease patients are observable according to the medical statistics in General Hospital, Anuradhapura. Hence, $4 \%$ of public health budget is allocated for renal disease treatment [13] (Figure 5).

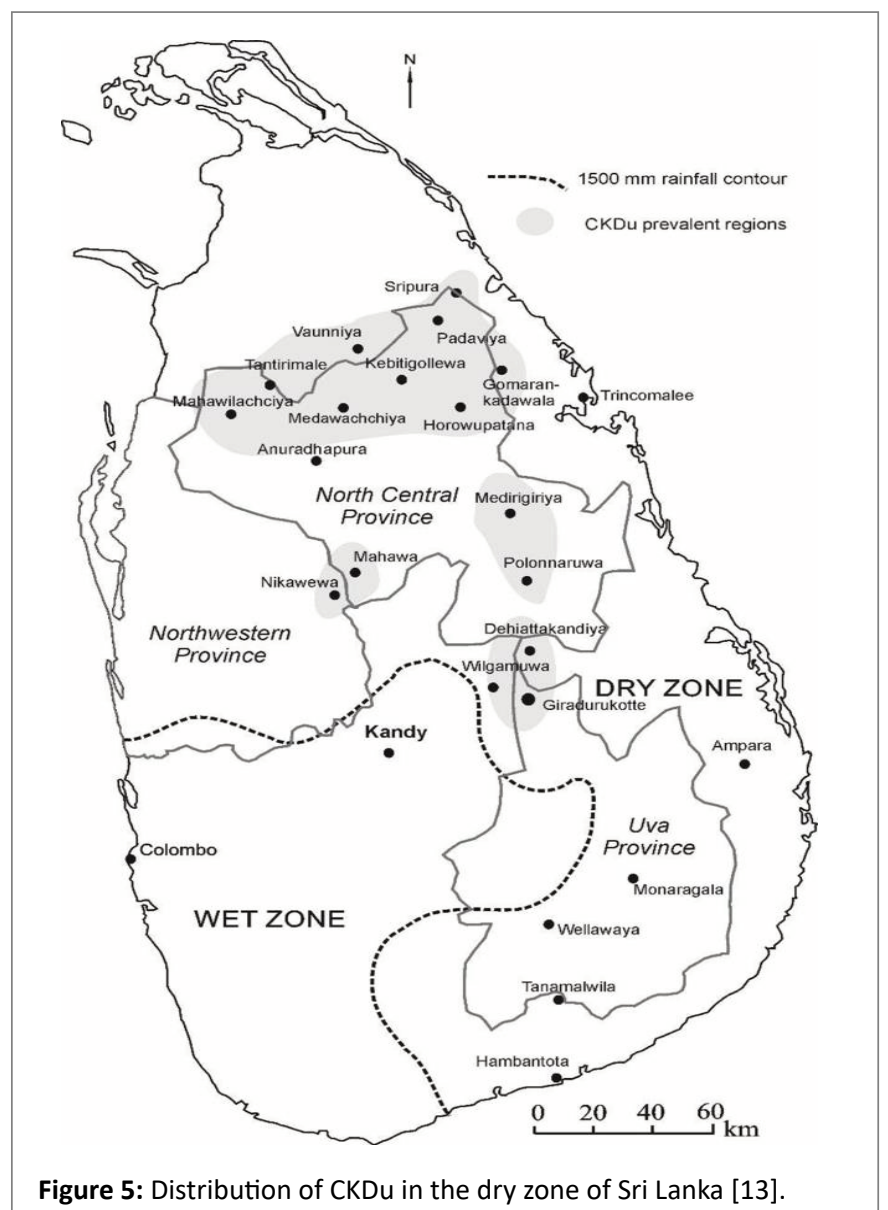


Geography of CKDu prevalent regions: NCP, where CKDu is most prevalent in Sri-Lanka is the country's largest province with two districts namely Anuradhapura to which Kebithigollewa belongs to and Polonnaruwa. NCP covers $16 \%$ of the country's total land area with 3,742 villages and approximately 1.3 million total population. NCP is belong to country's dry zone and is characterized by a hot climate with little rainfall. Its temperature ranges from $24.7-33^{\circ} \mathrm{C}$ with a $1,368 \mathrm{~mm}$ average rainfall occurring at 3 monsoons throughout the year which are North-East monsoon from December-February with the highest rainfall, Second-Inter monsoon from October-November and SouthWest monsoon from May-September with a little rainfall $[4,9]$.

Socio-demographics: Majority of NCP's people are Buddhists and their main occupation is agriculture which generates $30 \%$ of income NCP. Mostly males do agricultural work in fields and are aged $20 \mathrm{yrs}$ above. They work at least for 6-8 hrs/day but earn a very low income which depends on their harvest. Most of its individuals haven't completed a good level of school education where only $25 \%$ have gained the minimum accepted school qualifications in Sri Lanka which are Ordinary and Advanced Levels. Numbers of households is over two in most families and have at least one affected member. Climatic demographics and working hours are similar when compared to other CKDu affected countries; expect for the type of plantations farmed [9].

\section{Relationship between social and occupation risk factors}

The personal life of a person, family, education and work are greatly interconnected to each other that each will inherently influence the other and such these socioeconomic conditions are required in maintenance of a minimum living condition. Hence, the socioeconomic status of a person is best represented by education, occupation and income [20]. For example, lacking of proper education will prevent a person being able to have a job with less labour and high income, leading to poverty and unhealthy life [13].

\section{Important findings on CKDu in sri lanka over the years}

Though neurotoxic aluminum fluoride, formed by fluoride available at higher levels in water reacting with aluminum in low-quality aluminum utensils used at $\mathrm{CKDu}$ endemic areas, is hypothesized as a putative caustic of $\mathrm{CKDu}$ in Sri Lanka, a rapid rise of $\mathrm{CKDu}$ patients' number has been observed even after limiting low-quality aluminum utensil use. And Alzheimer's disease which is also caused by aluminum fluoride was not observable among the $\mathrm{CKDu}$ patients. Similarly, though cadmium from agrochemicals is hypothesized as a potential causative of $\mathrm{CKDu}$, studies have later shown that there're no such higher levels of cadmium present in either food or drinking water in CKDu endemic regions. Also, though toxins of Cyanobacteria like microbial toxins from freshwater bodies are hypothesized as a probable causative, there hasn't been any plausible evidence to show the development of CKDu among those who don't drink surface waters. Thus, the aetiology of CKDu remained uncertain [21]. But a shocking hypothesis was put forward in 2010 which is that the cause of $\mathrm{CKDu}$ would be arsenic poisoning. Higher levels of arsenic have been observed in rice produced in CKDu endemic areas and groundwater there, also in urine, hair, and other parts of the patient body, supporting the hypothesis. Palms and soles keratosis and hyperpigmentation which are symptoms of arsenic poisoning have also been observed in CKDu patients [22].

This arsenic which is coming from pesticides and other fertilizers react with calcium in hard water forming calcium arsenate crystals which interrupts renal tissues' antioxidant defense system when get into kidneys. Therefore this hypothesis been further evident arsenic deposits have been found in patients' diseased kidneys during postmortem tests. Yet the real causative to $\mathrm{CKDu}$ occurrence is unknown [23].

\section{Study purpose}

The research is focused on the least studied socioeconomic aspect of CKDu in Sri Lanka [20] with the main aim to identify the social and occupational risk factors associated with CKDu patients living in an agricultural community in Kebithigollawa, which is a village in the highest CKDu prevalent NCP's Anuradhapura District, Sri Lanka. Since CKDu has become a major health burden of the country, this research would be important in identifying risk factors associated with the disease and would be supportive for the ongoing researches on CKDu.

Specific objectives: With the main objective of this study to identify how a person's occupation, income, lifestyle and the social behaviours influence the cause and spread of CKDu, the specific objectives are to make descriptive statistics of the study population; find out associated occupational risk factors with $\mathrm{CKDu}$; find out associated social risk factors with $\mathrm{CKDu}$; identify why $\mathrm{CKDu}$ is more prominent in agricultural communities; look the impact of agrochemicals on $\mathrm{CKDu}$; check the effect of BMI on serum creatinine in CKDu patients; see the prevalence of the disease among the family members.

\section{Materials and Method}

\section{Design}

This research is a community based cross sectional study done during a three months period from December 2019 to March 2020.

\section{Setting}

The research was carried out at the CKDu Ayurvedic Clinic in Kebithigollewa, NCP, Sri Lanka.

\section{Patients and controls}

This research involves 30 patients diagnosed with CKDu who were attending the Kebithigollewa CKDu Ayurvedic Clinic, NCP, Sri Lanka. Initially a sample size of 35 was taken out of which only 30 people were long-term residents of the NCP hence, 30 case samples were chosen for the study. 30 people from the general public of NCP who were its long-term residents and who were not diagnosed with $\mathrm{CKDu}$ (unaffected) were randomly taken as control for the study.

Inclusion and exclusion criteria: All the participants were taken from long-term residents of NCP. Patients' past medical records were checked and selected only those who had a serum creatinine level of more than $1.2 \mathrm{mg} / \mathrm{dL}$ over a period of six consecutive months, as the case participants for the study. General public including the family members of the patients who were attending the clinic for screening purpose were randomly chosen and their blood samples were tested for serum creatinine levels. Only those who had a serum creatinine level below $1.2 \mathrm{mg} / \mathrm{dL}$ for three consecutive months were included for the study as control participants. Anyone who didn't fulfill these inclusion criteria was excluded.

\section{Data collected}

Biochemical, anthropometric, socio-demographic and socioeconomic data were collected from the CKDu diagnosed patients and general public of NCP who attended the CKDu Ayurvedic Clinic in Kebithigollewa in December 2019, January and February 2020. 


\section{Overview of the study procedure}

The study was carried out on a monthly basis for three consecutive months at the CKDu Ayurvedic Clinic, Kebithigollewa. Prior to the investigations all participants were detailed regarding the research and their consents were taken for the use and publication of the data. Samples of blood were withdrawn from participants with the help of a phlebotomist and lab technician for analysis of serum creatinine results. The samples were collected using universal guidelines of collection following the protocols stated by the laboratory standards. An interview based questionnaire was administered to the participants where data was collected from affected individuals as cases and unaffected general public of NCP who acted as controls for the study. All the collected data was computed and analysed.

\section{Questionnaires}

The questionnaires were filled up by interviewing the participants. Those were consisted of close ended questions and few open ended questions covering up their socio-demographic information (age, gender, ethnicity, civil status, duration of stay in NCP), medical history (number of years suffering from $\mathrm{CKDu}$, other diagnosed illnesses, family history of $\mathrm{CKDu}$ ), work history (occupation, number of hours working per day, monthly income, duration of heat/ sun exposure), work related exposure to chemicals (exposure to agrochemicals, duration of use of agrochemicals per year, use of protection when handling agrochemicals), education, personal fitness (Body Mass Index $\{B M I\}$, level of stress, number of hours sleeping per day, exercising, engagement in physical activities), consumption related habits (dietary habits, amount of water intake per day and source, consumption of tobacco \{smoking\}/ alcohol/ betel), level of social interactions and details of households (number of household members, their education, occupations, total monthly income).

\section{Socio-demographic and socio-economic data}

Participants age, gender, ethnicity, civil status, duration of stay in North Central Region, information regarding education and occupation were collected.

\section{Anthropometric measurements}

Participants' heights and weights were measured using a tape and a portable digital balance respectively, as physical measurements. It was then used to calculate their BMIs using the formula BMI= Weight $(\mathrm{kg}) /$ Height $\left(\mathrm{m}^{2}\right)$.

\section{Biochemical parameters}

Samples of blood were collected from the participants to test their serum creatinine levels. $3 \mathrm{ml}$ of venous blood was withdrawn from each participant, following universal precautions by a qualified phlebotomist using a syringe and was collected into plain tubes labeled with patients' clinic patient code and a unique registration number given for cases and controls respectively. It was then centrifuged at $3200 \mathrm{rpm}$ (rounds per minute) for 5 minutes using bench-top centrifugation to separate serum from blood. Separated serum samples were transported to laboratory storing in $1.5 \mathrm{~mL}$ Eppendorf tubes at $4^{\circ} \mathrm{C}$. With the use of fully automated blood analyzer TECOM TC-220, the samples of serum were analyzed by a qualified laboratory technician. Serum Creatinine values were obtained using Jaffe's reaction of Calorimetric Enzymatic Assay, which was then used to calculate the eGFR values using the CKD-EPI equation.

\section{Data analysis}

Descriptive statistics was used to differentiate the data collected according to collected patient demographics. Using the CKD-EPI equation the eGFR values were calculated and using this, the stages of $\mathrm{CKDu}$ were differentiated accordingly. Biochemical parameters were analyzed using Pearson correlation test and $\mathrm{p}$ values were obtained for the correlations carried out. Using Pearson correlation and Spearman rho tests, the association between serum creatinine and BMI was identified with a slightly positive correlation where a best fitted line was plotted. The correlation of the multi-dimensional questionnaire was calculated using Cramer's V square test, from which the most significant variables were taken to build regression models to understand the significance of the variables. A logistic regression was built to determine the relationship between working hours and serum creatinine, after which the one-way ANOVA test was done to find its significance. The level of significance for all statistical tests was considered as $\mathrm{p}<0.05$. SPSS version 20 and GraphPad Prism 8 were used for the analysis.

\section{Results}

\section{Characteristics of study population}

The study was done with 60 participants including cases and controls in 1:1 ratio. They were all (100\%) long-term residents of NCP and $98.3 \%$ of them were Sinhalese (1.7\% were Tamil). There was an overall response rate of $92.3 \%$. All the CKDu patients and $73.33 \%$ of the controls were married individuals while the rest were single. The other results obtained by assessing the socio-demographic, socioeconomic, anthropometric and biochemical data; medical history of study participants is summarized below.

Gender distribution: Majority (70\%) of the patients were males showing that the disease is more common among males than females. As presented in figure 6, the affected female to male ratio is approximately $1: 2$.

Age distribution: All patients participated in the study were aged above 40 yrs (Table 1) evidencing that CKDu is mostly seen among 40-60 yrs of aged individuals [13]. The mean age of patients was $59.5 \pm 0.5 \mathrm{yrs}$.

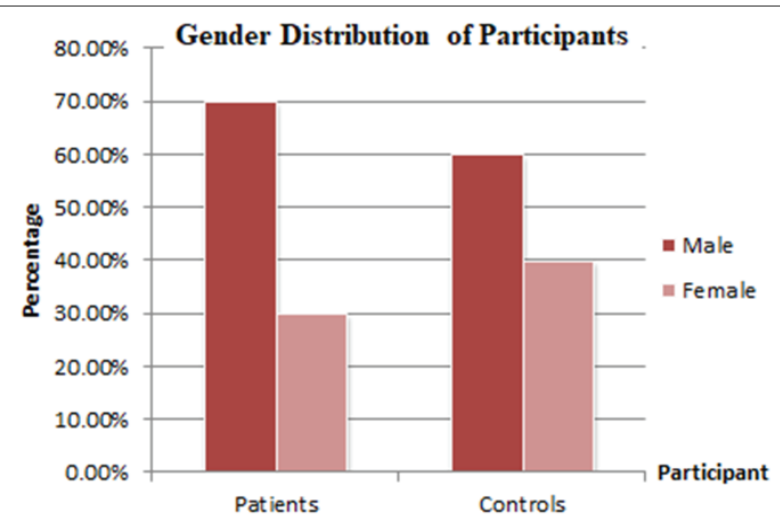

Figure 6: Participants' gender distribution.

Table 1: Participants' age distribution.

\begin{tabular}{|l|c|c|c|c|c|}
\hline \multirow{3}{*}{ Factor } & \multirow{2}{*}{ Level (years) } & \multicolumn{2}{|c|}{ Controls(30) } & \multicolumn{2}{c|}{ Cases(30) } \\
\cline { 3 - 6 } & & Number & Percentage & Number & Percentage \\
\hline \multirow{4}{*}{ Age } & $20-30$ & 5 & $16.67 \%$ & 0 & $0.00 \%$ \\
\cline { 2 - 6 } & $31-40$ & 7 & $23.33 \%$ & 0 & $0.00 \%$ \\
\cline { 2 - 6 } & $41-50$ & 5 & $16.67 \%$ & 6 & $20.00 \%$ \\
\cline { 2 - 6 } & $51-60$ & 8 & $26.67 \%$ & 11 & $36.67 \%$ \\
\cline { 2 - 6 } & $61-70$ & 3 & $10.00 \%$ & 8 & $26.67 \%$ \\
\cline { 2 - 6 } & $>70$ & 2 & $6.67 \%$ & 5 & $16.67 \%$ \\
\hline
\end{tabular}


Gender wise age category comparisons were done (Figure 7) to check if the most prone age of affection varies with gender. Both genders were seen to be highly affected between 51-60 yrs than other age categories.

Number of years living since CKDu diagnosed: $60 \%$ of patients were living for $1-5 \mathrm{yrs}$ with CKDu whereas only $20 \%$ where living for $>10$ yrs (Table 2).

By assessing this factor it was also able to identify $53 \pm 0.5 \mathrm{yrs}$ as the mean presentation age and that $46.67 \%$ of patients were in $35-50 \mathrm{yrs}$ age range when diagnosing the disease (Figure 8).

Variation of BMI: BMI values calculated were grouped into $\leq$ $18.530 \mathrm{~kg} / \mathrm{m}^{2},>18.5 \leq 2530 \mathrm{~kg} / \mathrm{m}^{2},>25 \leq 3030 \mathrm{~kg} / \mathrm{m}^{2}$ and $>30 \mathrm{~kg} / \mathrm{m}^{2}$ as underweight, normal, overweight and obese, respectively. All the patients participated for the study were having a BMI either normal or overweight, while there were controls from each category (Table 3).

Table 2: Number of years living since CKDu diagnosed.

\begin{tabular}{|l|c|c|c|}
\hline \multirow{2}{*}{ Factor } & \multirow{2}{*}{ Level (years) } & \multicolumn{2}{|c|}{ Cases } \\
\cline { 2 - 4 } & & Number & Percentage \\
\hline \multirow{3}{*}{$\begin{array}{l}\text { No. of Years Suffering } \\
\text { with the Disease }\end{array}$} & $<1$ & 1 & $3.33 \%$ \\
\cline { 2 - 4 } & $1-5$ & 18 & $60.00 \%$ \\
\cline { 2 - 4 } & $5-10$ & 5 & $16.67 \%$ \\
\cline { 2 - 4 } & $>10$ & 6 & $20.00 \%$ \\
\hline
\end{tabular}

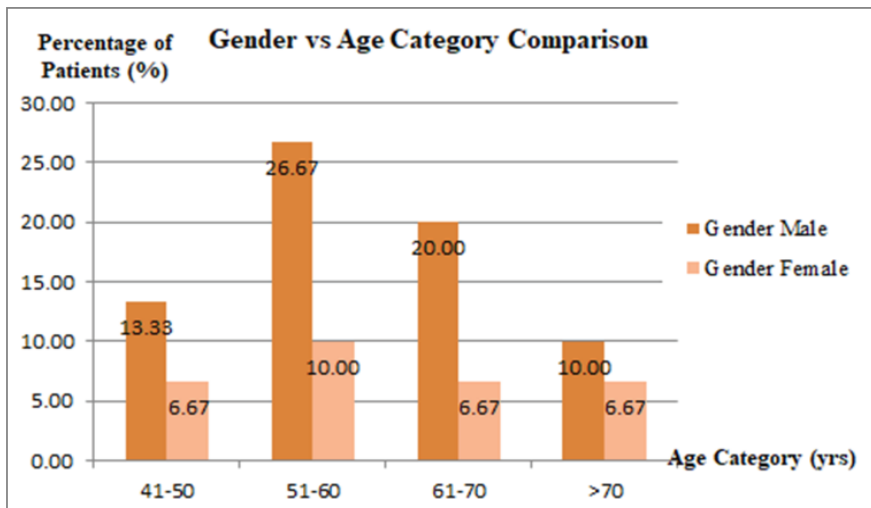

Figure 7: Patients' gender versus age category comparison.

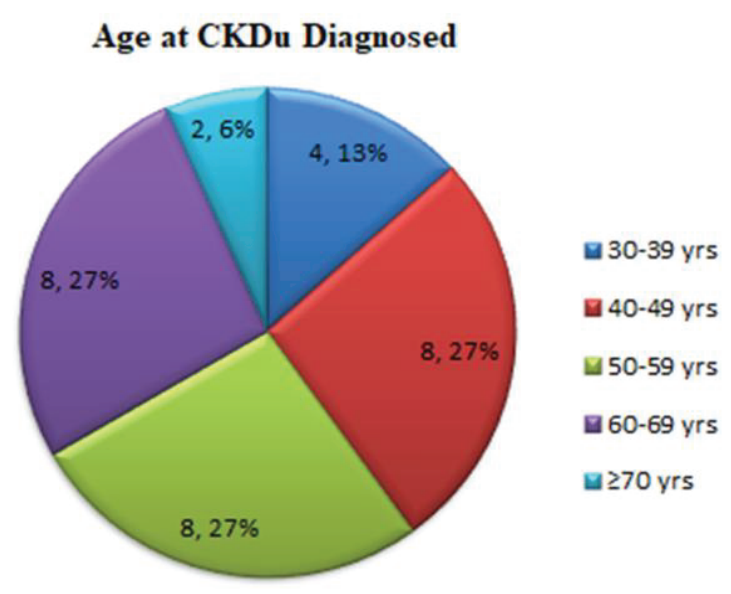

Figure 8: Age of patients when CKDu is diagnosed.
Table 3: BMIs of participants.

\begin{tabular}{|c|c|c|c|c|c|}
\hline \multirow{3}{*}{ Factor } & \multirow{2}{*}{ Level } & \multicolumn{2}{|c|}{ Controls } & \multicolumn{2}{c|}{ Cases } \\
\cline { 3 - 6 } & & Number & Percentage & Number & Percentage \\
\hline \multirow{4}{*}{ BMI } & Underweight & 5 & $16.67 \%$ & 0 & $0.00 \%$ \\
\cline { 2 - 6 } & Normal & 20 & $66.67 \%$ & 11 & $36.67 \%$ \\
\cline { 2 - 6 } & Overweight & 1 & $3.33 \%$ & 19 & $63.33 \%$ \\
\cline { 2 - 6 } & Obese & 4 & $13.33 \%$ & 0 & $0.00 \%$ \\
\hline
\end{tabular}

Medical history: Diabetes, High Blood Pressure and wheeze which are commonly seen in CKDs were specially assessed and found that 43.33\% of the cases were having High Blood Pressure but at the same time that $33.33 \%$ were not having any other diseases or illnesses (Table 4). Few of the patients complained of backache, foot pain and itching. $60 \%$ of the affected members were having at least one other affected member in their families either living or dead.

Variation of stress level: Half of the participants were not stressed while $20 \%$ of the patients were under high level of stress (Figure 9).

Participants' number of hours sleeping per day: $46.67 \%$ of the affected participants weren't getting at least $6 \mathrm{hrs}$ of sleep and most of them were complaining of interrupted sleep, but the unaffected were getting an adequate amount of sleep of 6-8 hrs (Table 5).

Level of social interactions: Half of the patients were having moderate and high levels of social interactions (Figure 10).

Family size: The average family size of participants was 3.27 . Their family household numbers are shown in table 6 .

Educational level of participants and their households: $66.67 \%$ of the CKDu patients have had schooled only for less than $10 \mathrm{yrs}$ and only $33.33 \%$ of them have gained at least the minimum required school education accepted in the country which is $\mathrm{O} / \mathrm{L}$ (Ordinary Level) or A/L (Advanced Level). But at least one household member of $73.34 \%$ of them has been able to achieve that minimum requirement (Table 7).

Occupations of participants: Even though all patients have had some involvement in farming at least at some point in their lives, $86.66 \%$ of cases were involved in farming either full-time or part-time as their livelihood. Even all other patients have had some involvement in farming at least at some point in their lives. But when it's compared with controls (Table 8), it can be seen that not all farms of NCP are diseased. Most of the affected individuals who had government sector occupations were involved in defense while few were teachers.

Education of patients were compared with their occupations (Figure 11) to find if there's an influence of education for them to choose agriculture as their main source of income and as expected majority of them had only 1-5 yrs of school education, hence were farming. Majority of controls were at least educated up to $\mathrm{O} / \mathrm{L}$ and hence were involved in either private or government jobs.

Number of employed other family members and their occupations: $50 \%$ of the affected had no other earning member in their families while $16.67 \%$ of those earning were involved in agriculture (Table 9).

Total monthly income: Majority of the patients were from low income families where $46.67 \%$ of them were getting only a total monthly family income of LKR 1,500-10,000 (Table 10). When the monthly income of a patient alone was considered, $63.33 \%$ were getting only LKR $0-10,000$. Monthly income of the farmers was completely dependent on their harvest obtained.

Number of hours working, exposure to sun, level of physical activity and engagement in exercises: $60 \%$ of the patients were engaged 


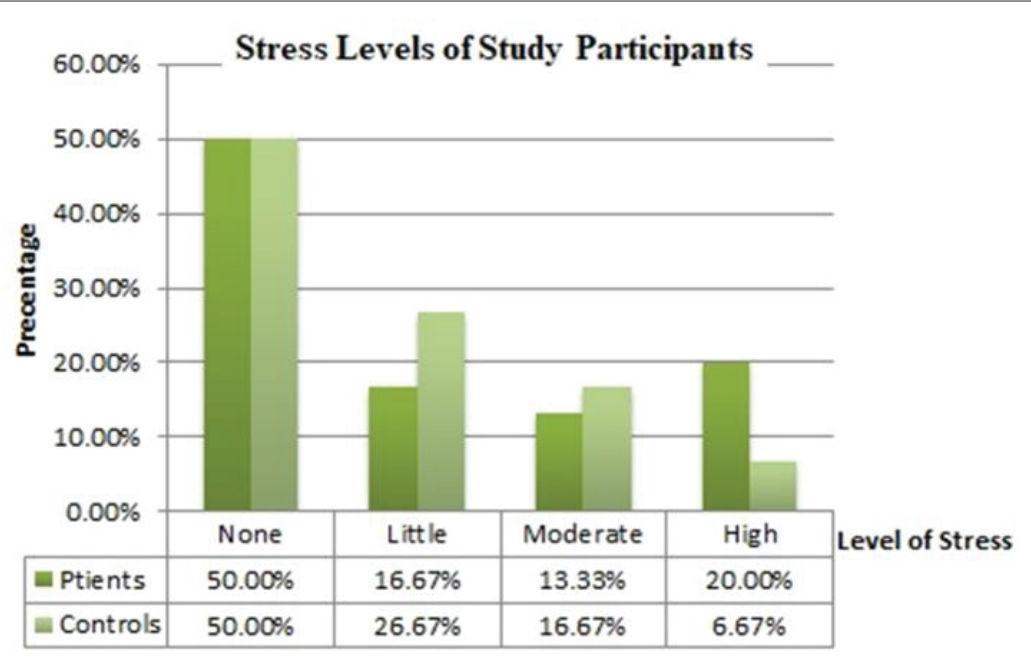

Figure 9: Participants' level of stress.

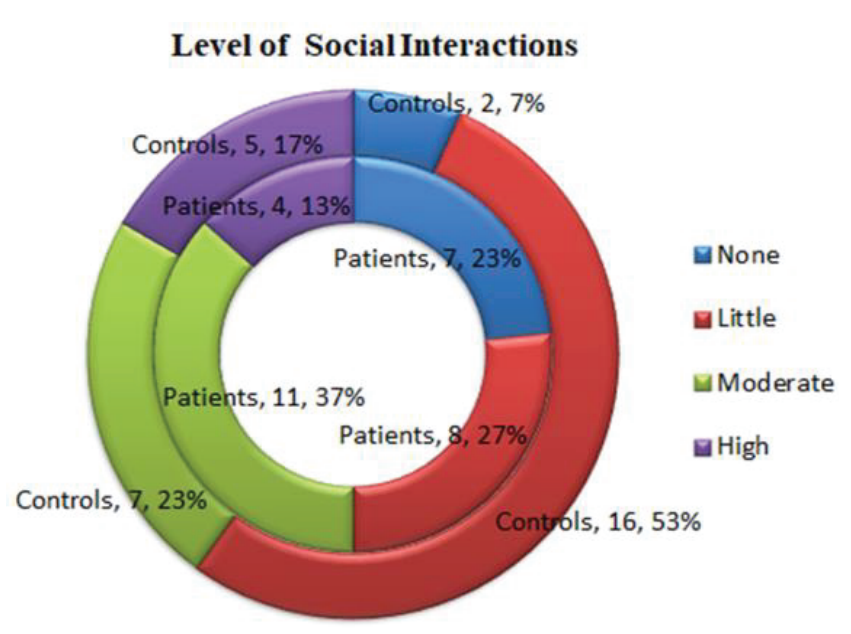

Figure 10: Participants' level of social interactions.

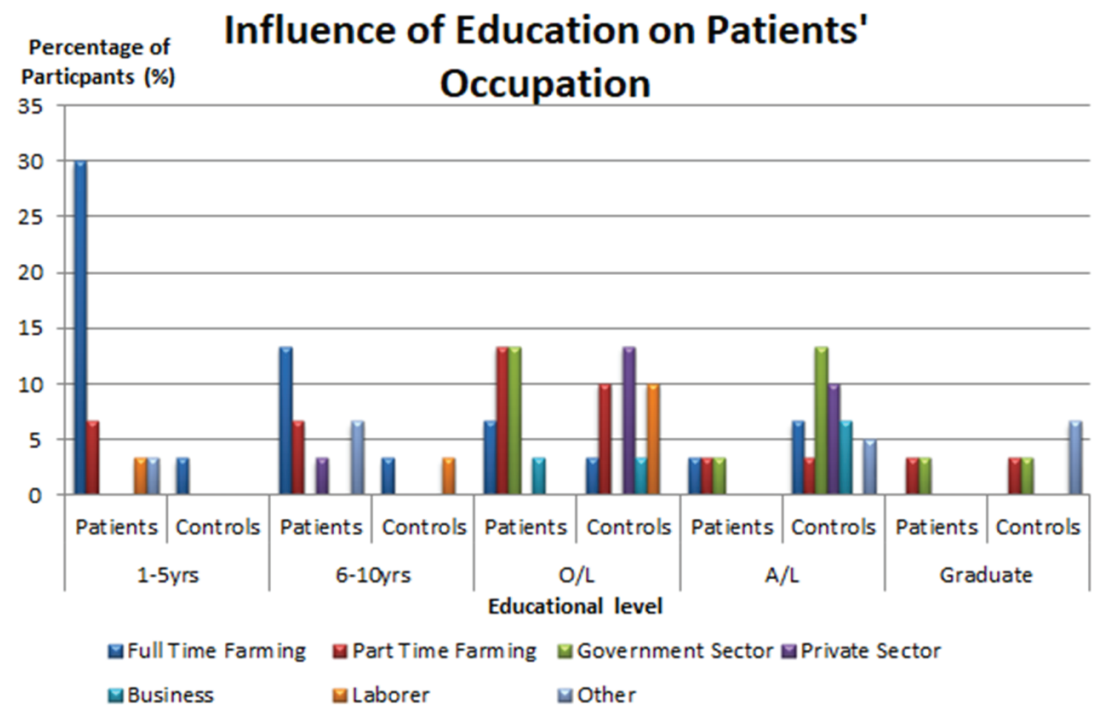

Figure 11: Influence of participants' education on their occupation. 
Table 4: Participants medical history and their family history for CKDu.

\begin{tabular}{|c|c|c|c|c|c|}
\hline \multirow{2}{*}{ Factor } & \multirow{2}{*}{ Level } & \multicolumn{2}{|c|}{ Controls } & \multicolumn{2}{|c|}{ Cases } \\
\hline & & Number & Percentage & Number & Percentage \\
\hline \multirow{5}{*}{$\begin{array}{l}\text { Other } \\
\text { Diseases } \\
\text { Diagnosed }\end{array}$} & Diabetes & 8 & $26.67 \%$ & 5 & $16.67 \%$ \\
\hline & $\begin{array}{l}\text { High Blood } \\
\text { Pressure }\end{array}$ & 4 & $13.33 \%$ & 13 & $43.33 \%$ \\
\hline & Wheeze & 0 & $0.00 \%$ & 3 & $10.00 \%$ \\
\hline & Other & 9 & $30.00 \%$ & 12 & $40.00 \%$ \\
\hline & None & 15 & $50.00 \%$ & 10 & $33.33 \%$ \\
\hline \multirow{4}{*}{$\begin{array}{l}\text { Number } \\
\text { of Family } \\
\text { Members } \\
\text { Affected } \\
\text { with CKDu }\end{array}$} & 1 & 2 & $0.00 \%$ & 14 & $46.67 \%$ \\
\hline & 2 & 0 & $0.00 \%$ & 1 & $3.33 \%$ \\
\hline & $\geq 3$ & 0 & $0.00 \%$ & 3 & $10.00 \%$ \\
\hline & None & 28 & $93.33 \%$ & 12 & $40.00 \%$ \\
\hline
\end{tabular}

Table 5: Participants' number of hours sleeping per day.

\begin{tabular}{|l|c|c|c|c|c|}
\hline \multirow{2}{*}{ Factor } & \multirow{2}{*}{ Level } & \multicolumn{2}{|c|}{ Controls } & \multicolumn{2}{c|}{ Cases } \\
\cline { 2 - 6 } & & Number & Percentage & Number & Percentage \\
\hline \multirow{2}{*}{$\begin{array}{l}\text { No. of Hours } \\
\text { Sleeping per } \\
\text { Day }\end{array}$} & $<6$ & 4 & $13.33 \%$ & 14 & $46.67 \%$ \\
\cline { 2 - 6 } & $6-8$ & 25 & $83.33 \%$ & 8 & $26.67 \%$ \\
\cline { 2 - 6 } & $>8$ & 1 & $3.33 \%$ & 8 & $26.67 \%$ \\
\hline
\end{tabular}

Table 6: Family Size.

\begin{tabular}{|l|c|c|c|c|c|}
\hline \multirow{2}{*}{ Factor } & \multirow{2}{*}{ Level } & \multicolumn{2}{|c|}{ Controls } & \multicolumn{2}{c|}{ Cases } \\
\cline { 2 - 6 } & & Number & Percentage & Number & Percentage \\
\hline $\begin{array}{l}\text { Number of } \\
\text { Members } \\
\text { in the } \\
\text { Household }\end{array}$ & $1-2$ & 8 & $26.67 \%$ & 12 & $40.00 \%$ \\
\cline { 2 - 6 } & $3-5$ & 21 & $70.00 \%$ & 18 & $60.00 \%$ \\
\cline { 2 - 6 } & $6-8$ & 1 & $3.33 \%$ & 0 & $0.00 \%$ \\
\hline
\end{tabular}

Table 7: Participants' and their families' level of education.

\begin{tabular}{|c|c|c|c|c|c|}
\hline \multirow{2}{*}{ Factor } & \multirow{2}{*}{ Level } & \multicolumn{2}{|c|}{ Controls } & \multicolumn{2}{|c|}{ Cases } \\
\hline & & Number & Percentage & Number & Percentage \\
\hline \multirow{7}{*}{$\begin{array}{l}\text { Level of } \\
\text { Education }\end{array}$} & $\begin{array}{c}\text { Primary } \\
\left(1^{\text {st }}-5^{\text {th }} y r s\right)\end{array}$ & 1 & $3.33 \%$ & 12 & $40.00 \%$ \\
\hline & $\begin{array}{c}\text { Middle } \\
\left(6^{\text {th }}-10^{\text {th }} y r s\right)\end{array}$ & 2 & $6.67 \%$ & 8 & $26.67 \%$ \\
\hline & $\mathrm{O} / \mathrm{L}\left(11^{\mathrm{th}} \mathrm{yr}\right)$ & 9 & $30.00 \%$ & 7 & $23.33 \%$ \\
\hline & $\begin{array}{c}\mathrm{A} / \mathrm{L}\left(12^{\text {th }}-\right. \\
\left.14^{\text {th }} \mathrm{yrs}\right)\end{array}$ & 15 & $50.00 \%$ & 2 & $6.67 \%$ \\
\hline & Graduate & 0 & $10.00 \%$ & 1 & $3.33 \%$ \\
\hline & Other & 0 & $0.00 \%$ & 0 & $0.00 \%$ \\
\hline & None & 0 & $0.00 \%$ & 0 & $0.00 \%$ \\
\hline \multirow{7}{*}{$\begin{array}{l}\text { Level of } \\
\text { Education of } \\
\text { the Member } \\
\text { with the } \\
\text { Highest } \\
\text { Educational } \\
\text { Qualification }\end{array}$} & Primary & 0 & $0.00 \%$ & 5 & $16.67 \%$ \\
\hline & Middle & 0 & $0.00 \%$ & 3 & $10.00 \%$ \\
\hline & $\mathrm{O} / \mathrm{L}$ & 9 & $30.00 \%$ & 5 & $16.67 \%$ \\
\hline & $A / L$ & 14 & $46.67 \%$ & 9 & $30.00 \%$ \\
\hline & Graduate & 7 & $23.33 \%$ & 8 & $26.67 \%$ \\
\hline & Other & 0 & $0.00 \%$ & 0 & $0.00 \%$ \\
\hline & None & 0 & $0.00 \%$ & 0 & $0.00 \%$ \\
\hline
\end{tabular}

Table 8: Participants' and their households' occupations.

\begin{tabular}{|c|c|c|c|c|c|}
\hline \multirow{2}{*}{ Factor } & \multirow{2}{*}{ Level } & \multicolumn{2}{|c|}{ Controls } & \multicolumn{2}{|c|}{ Cases } \\
\hline & & Number & Percentage & Number & Percentage \\
\hline \multirow{7}{*}{ Occupation } & $\begin{array}{c}\text { Full Time } \\
\text { Farming }\end{array}$ & 5 & $16.67 \%$ & 16 & $53.33 \%$ \\
\hline & $\begin{array}{l}\text { Part Time } \\
\text { Farming }\end{array}$ & 5 & $16.67 \%$ & 10 & $33.33 \%$ \\
\hline & Laborer & 4 & $13.33 \%$ & 1 & $3.33 \%$ \\
\hline & Business & 3 & $10.00 \%$ & 1 & $3.33 \%$ \\
\hline & $\begin{array}{l}\text { Private } \\
\text { Sector }\end{array}$ & 7 & $23.33 \%$ & 1 & $3.33 \%$ \\
\hline & $\begin{array}{c}\text { Government } \\
\text { Sector }\end{array}$ & 5 & $16.67 \%$ & 6 & $20.00 \%$ \\
\hline & Other & 7 & $23.33 \%$ & 3 & $10.00 \%$ \\
\hline
\end{tabular}

Table 9: Number of other members earning in participants' families and their occupations.

\begin{tabular}{|c|c|c|c|c|c|}
\hline \multirow{2}{*}{ Factor } & \multirow{2}{*}{ Level } & \multicolumn{2}{|c|}{ Controls } & \multicolumn{2}{|c|}{ Cases } \\
\hline & & Number & Percentage & Number & Percentage \\
\hline \multirow{4}{*}{$\begin{array}{l}\text { Number } \\
\text { of Other } \\
\text { Members } \\
\text { Working in } \\
\text { the Family }\end{array}$} & 1 & 12 & $40.00 \%$ & 12 & $40.00 \%$ \\
\hline & 2 & 8 & $26.67 \%$ & 1 & $3.33 \%$ \\
\hline & 3 & 2 & $6.67 \%$ & 2 & $6.67 \%$ \\
\hline & $>3$ & 0 & $0.00 \%$ & 0 & $0.00 \%$ \\
\hline \multirow{8}{*}{$\begin{array}{l}\text { Occupations } \\
\text { of the } \\
\text { Members of } \\
\text { Household }\end{array}$} & None & 8 & $26.67 \%$ & 15 & $50.00 \%$ \\
\hline & $\begin{array}{l}\text { Full Time } \\
\text { Farming }\end{array}$ & 1 & $3.33 \%$ & 3 & $10.00 \%$ \\
\hline & $\begin{array}{l}\text { Part Time } \\
\text { Farming }\end{array}$ & 4 & $13.33 \%$ & 2 & $6.67 \%$ \\
\hline & Laborer & 2 & $6.67 \%$ & 0 & $0.00 \%$ \\
\hline & Business & 0 & $0.00 \%$ & 0 & $0.00 \%$ \\
\hline & $\begin{array}{l}\text { Private } \\
\text { Sector }\end{array}$ & 9 & $30.00 \%$ & 2 & $6.67 \%$ \\
\hline & $\begin{array}{c}\text { Government } \\
\text { Sector }\end{array}$ & 5 & $16.67 \%$ & 8 & $26.67 \%$ \\
\hline & Other & 7 & $23.33 \%$ & 15 & $50.00 \%$ \\
\hline
\end{tabular}

Table 10: Total monthly income of participants' families.

\begin{tabular}{|l|c|c|c|c|c|}
\hline \multirow{4}{*}{ Factor } & Level (LKR) & \multicolumn{2}{|c|}{ Controls } & \multicolumn{2}{c|}{ Cases } \\
\cline { 3 - 6 } & Number & Percentage & Number & Percentage \\
\hline \multirow{4}{*}{$\begin{array}{l}\text { Total } \\
\text { Monthly }\end{array}$} & $1,500-10,000$ & 2 & $6.67 \%$ & 14 & $46.67 \%$ \\
\cline { 2 - 6 } & $10,000-20,000$ & 0 & $0.00 \%$ & 6 & $20.00 \%$ \\
\cline { 2 - 6 } $\begin{array}{l}\text { Income } \\
\text { of the }\end{array}$ & $20,000-30,000$ & 5 & $16.67 \%$ & 3 & $10.00 \%$ \\
\cline { 2 - 6 } Family & $30,000-40,000$ & 8 & $26.67 \%$ & 4 & $13.33 \%$ \\
\cline { 2 - 6 } & $40,000-50,000$ & 9 & $30.00 \%$ & 3 & $10.00 \%$ \\
\cline { 2 - 6 } & $50,000-100,000$ & 6 & $20.00 \%$ & 0 & $0.00 \%$ \\
\cline { 2 - 6 } & $>100,000$ & 0 & $0.00 \%$ & 0 & $0.00 \%$ \\
\hline
\end{tabular}


in heavy work for 8-11 hrs/day and most of them were males as males used to work in fields with comparatively little help of females. Their physical activity level was moderate and active in 1:1 ratio while only $13.33 \%$ were exercising. $95 \%$ of all participants were getting exposed to sun/heat for 10 or less hours daily (Table 11).

Effect of agrochemicals: Majority of participants were using agrochemicals while $53.34 \%$ among the cases were exposed to moderate/ higher levels of agrochemicals (Table 12). Most of them were using agrochemicals from days to weeks per year. Yet, $66 \%$ of patients never used protective measures (Figure 12). Even the patients who were using protective measures often used hand-gloves only.

Consumption related behaviours: $43.33 \%$ of affected were consuming untreated water and $63.33 \%$ were drinking $<3 \mathrm{~L} /$ day. Though most of the patients have stopped eating meat after disease diagnosis, $30 \%$ still then were non-vegetarians. $60 \%$ of patients were used to daily consumption of a lot of Betel while only few were consuming alcohol and smoking at the time of data collection (Table 13).

Results of biochemical data: Serum creatinine values of patients ranged between 1.3-2.8 $\mathrm{mg} / \mathrm{dL}$. CKDu stages of patients were found by calculating their eGFRs (Figure 13). No patients were reported in stages 1 and 5 .

Table 11: Number of working hours of participants, their exposure to sun/heat, level of physical activity and engagement in exercises.

\begin{tabular}{|l|c|c|c|c|c|}
\hline \multirow{2}{*}{ Factor } & Level & \multicolumn{2}{|c|}{ Controls } & \multicolumn{2}{c|}{ Cases } \\
\cline { 3 - 6 } & & Number & Percentage & Number & Percentage \\
\hline \multirow{3}{*}{$\begin{array}{l}\text { Number } \\
\text { of Hours } \\
\text { Working pe } \\
\text { Day }\end{array}$} & $1-4 \mathrm{hrs}$ & 3 & $10.00 \%$ & 3 & $10.00 \%$ \\
\cline { 2 - 6 } & $4-8 \mathrm{hrs}$ & 9 & $30.00 \%$ & 6 & $20.00 \%$ \\
\cline { 2 - 6 } & $8-11 \mathrm{hrs}$ & 14 & $46.67 \%$ & 18 & $60.00 \%$ \\
\cline { 2 - 6 } & $>11 \mathrm{hrs}$ & 1 & $3.33 \%$ & 2 & $6.67 \%$ \\
\cline { 2 - 6 } & Other & 3 & $10.00 \%$ & 1 & $3.33 \%$ \\
\hline $\begin{array}{l}\text { Duration of } \\
\text { Heat/Sun } \\
\text { Exposure }\end{array}$ & $<10 \mathrm{hrs}$ & 28 & $93.33 \%$ & 29 & $96.67 \%$ \\
\cline { 2 - 6 } & $>10 \mathrm{hrs}$ & 2 & $6.67 \%$ & 1 & $3.33 \%$ \\
\hline \multirow{2}{*}{$\begin{array}{l}\text { Engagement } \\
\text { in Physical } \\
\text { Activities }\end{array}$} & Inactive & 1 & $3.33 \%$ & 0 & $0.00 \%$ \\
\cline { 2 - 6 } & Moderate & 21 & $70.00 \%$ & 15 & $50.00 \%$ \\
\cline { 2 - 6 } & Active & 8 & $26.66 \%$ & 15 & $50.00 \%$ \\
\hline \multirow{3}{*}{ Exercising } & Yes & 4 & $13.33 \%$ & 4 & $13.33 \%$ \\
\cline { 2 - 6 } & Sometimes & 8 & $26.67 \%$ & 0 & $0.00 \%$ \\
\cline { 2 - 6 } & No & 18 & $60.00 \%$ & 26 & $86.67 \%$ \\
\hline
\end{tabular}

Table 12: Exposure to agrochemicals.

\begin{tabular}{|l|c|c|c|c|c|}
\hline \multirow{2}{*}{ Factor } & Level & \multicolumn{2}{|c|}{ Controls } & \multicolumn{2}{c|}{ Cases } \\
\cline { 2 - 6 } & & Number & Percentage & Number & Percentage \\
\hline \multirow{3}{*}{$\begin{array}{l}\text { Exposure to } \\
\text { Agrochemicals }\end{array}$} & None & 20 & $66.67 \%$ & 5 & $16.67 \%$ \\
\cline { 2 - 6 } & Little & 8 & $26.67 \%$ & 9 & $30.00 \%$ \\
\cline { 2 - 6 } & Moderate & 1 & $3.33 \%$ & 8 & $26.67 \%$ \\
\cline { 2 - 6 } & High & 1 & $3.33 \%$ & 8 & $26.67 \%$ \\
\hline \multirow{2}{*}{$\begin{array}{l}\text { Use of } \\
\text { Protection } \\
\text { when } \\
\text { Handling } \\
\text { Agrochemicals }\end{array}$} & Always & 7 & $70.00 \%$ & 3 & $10.00 \%$ \\
\cline { 2 - 6 } & Sometimes & 1 & $10.00 \%$ & 3 & $10.00 \%$ \\
\cline { 2 - 6 } & Never & 3 & $30.00 \%$ & 20 & $66.00 \%$ \\
\cline { 2 - 6 } & None & 0 & $0.00 \%$ & 4 & $13.33 \%$ \\
\hline
\end{tabular}

Table 13: Consumption related behaviours.

\begin{tabular}{|c|c|c|c|c|c|c|}
\hline \multirow{2}{*}{ Factor } & \multirow{2}{*}{\multicolumn{2}{|c|}{ Level }} & \multicolumn{2}{|c|}{ Controls } & \multicolumn{2}{|c|}{ Cases } \\
\hline & & & Number & Percentage & Number & Percentage \\
\hline \multirow{6}{*}{$\begin{array}{l}\text { Source of } \\
\text { Water }\end{array}$} & \multicolumn{2}{|l|}{ Well } & 7 & $23.33 \%$ & 5 & $16.67 \%$ \\
\hline & \multicolumn{2}{|c|}{ Tube Well } & 7 & $23.33 \%$ & 4 & $13.33 \%$ \\
\hline & \multicolumn{2}{|c|}{$\begin{array}{l}\text { Rain Water } \\
\text { Repository }\end{array}$} & 0 & $0.00 \%$ & 2 & $6.67 \%$ \\
\hline & \multicolumn{2}{|c|}{$\begin{array}{l}\text { Natural } \\
\text { Springs }\end{array}$} & 0 & $0.00 \%$ & 2 & $6.67 \%$ \\
\hline & \multicolumn{2}{|c|}{$\begin{array}{l}\text { Filtered } \\
\text { Water }\end{array}$} & 16 & $53.33 \%$ & 17 & $56.67 \%$ \\
\hline & \multicolumn{2}{|c|}{ Other } & 0 & $0.00 \%$ & 1 & $3.33 \%$ \\
\hline \multirow{2}{*}{$\begin{array}{l}\text { Amount of } \\
\text { Water Intake } \\
\text { per Day }\end{array}$} & \multicolumn{2}{|l|}{$<3 \mathrm{~L}$} & 13 & $43.33 \%$ & 19 & $63.33 \%$ \\
\hline & \multicolumn{2}{|l|}{$>3 \mathrm{~L}$} & 17 & $56.67 \%$ & 11 & $36.67 \%$ \\
\hline \multirow{2}{*}{$\begin{array}{l}\text { Dietary } \\
\text { Habits }\end{array}$} & \multicolumn{2}{|c|}{ Vegetarian } & 4 & $13.33 \%$ & 21 & $70.00 \%$ \\
\hline & \multicolumn{2}{|c|}{$\begin{array}{c}\text { Non } \\
\text { Vegetarian }\end{array}$} & 26 & $86.67 \%$ & 9 & $30.00 \%$ \\
\hline \multirow{6}{*}{$\begin{array}{l}\text { Consumption } \\
\text { of Alcohol/ } \\
\text { Betel/ } \\
\text { Smoking }\end{array}$} & \multirow{2}{*}{ Alcohol } & Yes & 8 & $26.67 \%$ & 10 & $33.33 \%$ \\
\hline & & No & 22 & $73.33 \%$ & 20 & $66.67 \%$ \\
\hline & \multirow{2}{*}{ Betel } & Yes & 4 & $13.33 \%$ & 18 & $60.00 \%$ \\
\hline & & No & 26 & $86.67 \%$ & 12 & $40.00 \%$ \\
\hline & \multirow{2}{*}{ Smoking } & Yes & 5 & $16.67 \%$ & 8 & $26.67 \%$ \\
\hline & & No & 25 & $83.33 \%$ & 22 & $73.33 \%$ \\
\hline
\end{tabular}

\section{Statistical analysis}

Descriptive statistics: The mean serum creatinine and eGFR of the study patients were $1.8067 \mathrm{mg} / \mathrm{dL}$ and $38.93 \mathrm{ml} / \mathrm{min} / 1.73 \mathrm{~m}^{2}$, respectively (Table 14).

The average serum creatinine levels are relatively lower in the females at 1.675 than the males at 1.894 (Table 15).

The age group, 31-50 yrs shows an overall increase in serum creatinine (Table 16).

Farming members and laborers showed the highest average of serum creatinine levels (Table 17).

A comparison bar chart was constructed where the two significant variables, gender and occupation were used to compare against serum creatinine and e-GFR levels (Figures 14 and 15). On average, the full time farming community shows the highest difference between genders with females having a significantly higher average value compared to males.

Correlation between the questionnaire variables and serum creatinine levels were calculated with Cramer's V square test (Table 18 ), out of which a significance of 0.64 between working hours and serum creatinine levels was seen.

Serum creatinine levels of patients were found to be increasing with increase of BMI (Figure 16). Its correlation found with Spearman rho is 0.453 and p-value is 0.012 , while Pearson $\mathrm{R}$ is 0.481 and p-value is 0.007 .

Nominal logistic regression: Using logistic regression, serum creatinine levels were compared with working hour patterns. Two models logit 1 and 2 were used (Tables 19-21). Logit 1 involved comparison 
Table 14: Descriptive statistics of the mean values of serum creatinine level $(\mathrm{mg} / \mathrm{dL})$ and e-GFR $\left(\mathrm{ml} / \mathrm{min} / 1.73 \mathrm{~m}^{2}\right)$.

\begin{tabular}{|l|c|c|c|c|c|}
\hline \multicolumn{1}{|c|}{ Variable } & Mean & SE Mean & St Dev & Minimum & Maximum \\
\hline $\begin{array}{l}\text { Serum Creatinine } \\
\text { Level }\end{array}$ & 1.8067 & 0.0693 & 0.3796 & 1.3000 & 2.8000 \\
\hline $\begin{array}{l}\text { eGFR }(\mathrm{ml} / \\
\left.\mathrm{min} / 1.73 \mathrm{~m}^{2}\right)\end{array}$ & 38.93 & 1.85 & 10.15 & 22.00 & 59.00 \\
\hline
\end{tabular}

Table 15: Gender wise comparison of serum creatinine and e-GFR.

\begin{tabular}{|l|c|c|c|c|c|c|}
\hline \multicolumn{1}{|c|}{ Variable } & Gender & Mean & SE Mean & St Dev & Minimum & Maximum \\
\hline $\begin{array}{l}\text { Serum } \\
\text { Creatinine } \\
\text { Level }\end{array}$ & Male & 1.8944 & 0.0965 & 0.4094 & 1.4000 & 2.8000 \\
\cline { 2 - 7 } & Female & 1.6750 & 0.0863 & 0.2989 & 1.3000 & 2.4000 \\
\hline $\begin{array}{l}\text { eGFR }(\mathrm{ml} / \\
\left.\text { min } / 1.73 \mathrm{~m}^{2}\right)\end{array}$ & Male & 36.78 & 2.45 & 10.41 & 22.00 & 59.00 \\
\cline { 2 - 7 } & Female & 42.17 & 2.67 & 9.23 & 26.00 & 59.00 \\
\hline
\end{tabular}

Table 16: Significance of serum creatinine levels in different age groups.

\begin{tabular}{|c|c|c|c|c|c|c|}
\hline Variable & Age & Mean & SE Mean & St Dev & Minimum & Maximum \\
\hline \multirow{6}{*}{$\begin{array}{l}\text { Serum } \\
\text { Creatinine } \\
\text { Level }\end{array}$} & $20-30$ & 1.800 & 0.221 & 0.495 & 1.300 & 2.600 \\
\hline & $31-40$ & 1.943 & 0.166 & 0.439 & 1.500 & 2.800 \\
\hline & $41-50$ & 1.880 & 0.159 & 0.356 & 1.400 & 2.400 \\
\hline & $51-60$ & 1.738 & 0.129 & 0.366 & 1.400 & 2.300 \\
\hline & $61-70$ & 1.667 & 0.219 & 0.379 & 1.400 & 2.100 \\
\hline & $>70$ & 1.6500 & 0.0500 & 0.0707 & 1.6000 & 1.7000 \\
\hline \multirow{6}{*}{$\begin{array}{l}\text { eGFR }(\mathrm{ml} / \\
\left.\min / 1.73 \mathrm{~m}^{2}\right)\end{array}$} & $20-30$ & 40.20 & 3.60 & 8.04 & 28.00 & 49.00 \\
\hline & $31-40$ & 38.29 & 3.79 & 10.03 & 22.00 & 52.00 \\
\hline & $41-50$ & 37.20 & 5.91 & 13.22 & 26.00 & 59.00 \\
\hline & $51-60$ & 40.25 & 4.00 & 11.32 & 25.00 & 59.00 \\
\hline & $61-70$ & 36.33 & 8.45 & 14.64 & 23.00 & 52.00 \\
\hline & $>70$ & 41.00 & 4.00 & 5.66 & 37.00 & 45.00 \\
\hline
\end{tabular}

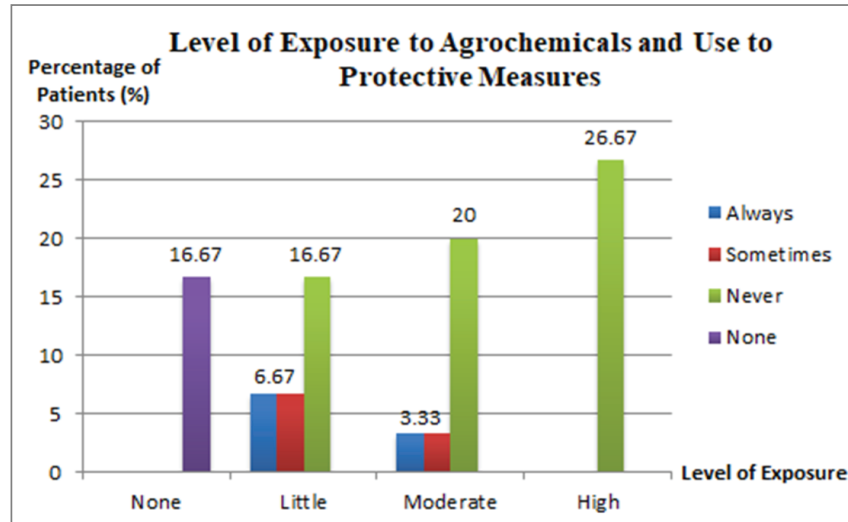

Figure 12: Patients' level of agrochemical exposure and use of protective measures while handling those.

Table 17: Serum creatinine against occupation.

\begin{tabular}{|c|c|c|c|c|c|c|}
\hline Variable & Occupation & Mean & SE Mean & St Dev & Minimum & Maximum \\
\hline \multirow{7}{*}{ Serum Creatinine Level } & Full Time Farming & 1.883 & 0.135 & 0.331 & 1.500 & 2.400 \\
\hline & Part Time Farming & 1.4000 & $*$ & $*$ & 1.4000 & 1.4000 \\
\hline & Government Sector & 1.725 & 0.111 & 0.222 & 1.400 & 1.900 \\
\hline & Private Sector & 2.100 & 0.225 & 0.551 & 1.300 & 2.800 \\
\hline & Business & 1.5000 & 0.000000 & 0.000000 & 1.5000 & 1.5000 \\
\hline & Laborer & 1.775 & 0.180 & 0.359 & 1.500 & 2.300 \\
\hline & Other & 1.700 & 0.115 & 0.306 & 1.400 & 2.300 \\
\hline \multirow{7}{*}{ eGFR (ml/min/1.73m²) } & Full Time Farming & 33.33 & 3.67 & 8.98 & 23.00 & 47.00 \\
\hline & Part Time Farming & 59.000 & $*$ & $*$ & 59.000 & 59.000 \\
\hline & Government Sector & 43.75 & 5.25 & 10.50 & 35.00 & 59.00 \\
\hline & Private Sector & 33.17 & 3.53 & 8.66 & 22.00 & 44.00 \\
\hline & Business & 37.500 & 0.500 & 0.707 & 37.000 & 38.000 \\
\hline & Laborer & 40.25 & 5.38 & 10.75 & 27.00 & 52.00 \\
\hline & Other & 42.71 & 3.58 & 9.46 & 25.00 & 52.00 \\
\hline
\end{tabular}

( *limited sample size available hence SE Mean and standard deviation cannot be found using statistical tests). 
Table 18: Correlation between questionnaire variables and serum creatinine.

\begin{tabular}{|l|c|}
\hline \multicolumn{1}{|c|}{ Variable } & Cramer's V square \\
\hline Age category & 0.242677 \\
\hline Level of stress & 0.166162 \\
\hline Exposure to Agrochemicals & 0.0534091 \\
\hline Consumption of alcohol & 0.0289256 \\
\hline Engagement in Physical Activities & 0.0330387 \\
\hline Consumption of Beetle & 0.0212843 \\
\hline Source of water & 0.0559441 \\
\hline Exercise & 0.165043 \\
\hline Number of working hours per day & $\mathbf{0 . 6 4 2 2 1 8}$ \\
\hline
\end{tabular}

Table 19: Logistic regression table: stage versus no. of hours working per day_1.

\begin{tabular}{|l|c|c|c|c|c|c|c|}
\hline Predictor & $\begin{array}{c}\text { Coefficient } \\
\text { (Coef) }\end{array}$ & SE Coef & Z Score & $\begin{array}{c}\text { P } \\
\text { Score }\end{array}$ & $\begin{array}{c}\text { Odds } \\
\text { Ratio }\end{array}$ & $\begin{array}{c}94 \% \\
\text { Lower }\end{array}$ & $\begin{array}{c}\text { CI } \\
\text { Upper }\end{array}$ \\
\hline \multicolumn{7}{|c|}{ Logit 1: (3/4) } \\
\hline Constant & 25.1210 & 86451.7 & 0.00 & 1.000 & & & \\
\hline
\end{tabular}

No. of Hours Working per Day_1

\begin{tabular}{|l|c|c|c|c|c|c|c|}
\hline 4-8hrs & -3.31639 & 87146.0 & -0.00 & 1.000 & 0.04 & 0.00 & $*$ \\
\hline $8-11 \mathrm{hrs}$ & -23.1751 & 86451.7 & -0.00 & 1.000 & 0.00 & 0.00 & $*$ \\
\hline$>11 \mathrm{hrs}$ & -25.8141 & 86451.7 & -0.00 & 1.000 & 0.00 & 0.00 & $*$ \\
\hline Other & -47.8639 & 101223 & -0.00 & 1.000 & 0.00 & 0.00 & $*$ \\
\hline
\end{tabular}

Logit 2: (2/4)

\begin{tabular}{|l|l|l|l|l|l|l|l|}
\hline Constant & 24.4278 & 86451.7 & 0.00 & 1.000 & & 0.00 & \\
\hline
\end{tabular}

No. of Hours Working per Day_1

\begin{tabular}{|l|c|c|c|c|c|c|c|}
\hline 4-8hrs & -25.5264 & 89196.4 & -0.00 & 1.000 & 0.00 & 0.00 & $*$ \\
\hline 8-11hrs & -45.1209 & 88492.0 & -0.00 & 1.000 & 0.00 & 0.00 & $*$ \\
\hline$>11 \mathrm{hrs}$ & -47.7839 & 93560.1 & -0.00 & 1.000 & 0.00 & 0.00 & $*$ \\
\hline Other & -49.5686 & 194852 & -0.00 & 1.000 & 0.00 & 0.00 & $*$ \\
\hline
\end{tabular}

between stage $3 / 4$ and working hours. Logit 2 involved comparison between stage $2 / 4$ and working hours. The p-value obtained was 0.004 on a whole the regression analysis and log likelihood was -10.652 . Test that all slopes are zero: $\mathrm{G}$ was 22.488 and DF was 8 .

Regression model was made for serum creatinine level and BMI with the regression equation serum creatine level (mg/ $\mathrm{dL})=-0.0165+0.07455 \mathrm{BMI} \_1 \quad$ resulted $\mathrm{S}=0.298292, \quad \mathrm{R}-\mathrm{Sq}=23.1 \%$, $\mathrm{R}-\mathrm{Sq}(\mathrm{adj})=20.4 \%$.

Line of best fit drawn (Figure 17) showed a linear relationship between serum creatinine and BMI.

ANOVA test comparison between working hours: Equal variances were assumed for the analysis as shown in table 22.

The $\mathrm{p}$-value obtained for the comparison of variance shows that $\alpha$ is $<0.05$, hence the alternative hypothesis is accepted where the average serum creatinine levels vary between working hours.
Table 20: Tests for terms with more than 1 degree of freedom.

\begin{tabular}{|l|c|c|c|}
\hline \multicolumn{1}{|c|}{ Term } & Chi-Square & DF & P \\
\hline $\begin{array}{l}\text { Logit 1: (3/4) No. of hours } \\
\text { working per day_1 }\end{array}$ & 3.67943 & 4 & 0.451 \\
\hline $\begin{array}{l}\text { Logit 2: (2/4) No. of hours } \\
\text { working per day_1 }\end{array}$ & 0.00000 & 4 & 1.000 \\
\hline
\end{tabular}

Table 21: Analysis of Variance: serum creatinine level versus BMI_1.

\begin{tabular}{|l|c|c|c|c|c|}
\hline \multicolumn{1}{|c|}{ Source } & Df & Adj SS & Adj MS & F-Value & P-Value \\
\hline Regression & 1 & 0.75028 & 0.750278 & 8.43 & 0.007 \\
\hline Error & 28 & 2.49139 & 0.088978 & & \\
\hline Total & 29 & 3.24167 & & & \\
\hline
\end{tabular}

Table 22: Analysis of variance (serum creatinine level $(\mathrm{mg} / \mathrm{dL}$ ) versus number of hours working per day_1).

\begin{tabular}{|l|c|c|c|c|c|}
\hline \multicolumn{1}{|c|}{ Source } & Df & Adj SS & Adj MS & F-Value & P-Value \\
\hline $\begin{array}{l}\text { No. of hours } \\
\text { working per day_1 }\end{array}$ & 4 & 2.173 & 0.54325 & 6.23 & 0.001 \\
\hline Error & 25 & 2.182 & 0.08727 & & \\
\hline Total & 29 & 4.355 & & & \\
\hline
\end{tabular}

$\mathrm{H}_{0}=$ All means are equal; $\mathrm{H}_{1}=$ At least one mean is different; Significance level $\alpha=0.05$.

There is a clear positive relationship between working hours and serum creatinine levels (Figure 18), the higher the working hours the higher the serum creatinine levels go.

\section{Discussion}

Socioeconomic, socio-demographic, anthropometric and biochemical data of $30 \mathrm{CKDu}$ diagnosed patients (cases) and 30 unaffected individuals (controls) have been interviewed and examined in this study. Since CKDu is prevalent in subtropical and tropical areas around the world [24] and it's most commonly seen in NCP of Sri Lanka which is one of the driest regions in the country there have been high number of reported CKDu cases being observed. Anuradhapura district has been reported with the highest number of affected [1] hence, Kebithigollewa was selected as the study setting as it is one of the most affected cities in the region. The selection criteria focused on selecting participants who were long-term residents of NCP to observe if the climate has an impact on CKDu disease occurrence and why $\mathrm{CKDu}$ is more prominent in NCP. Since questionnaires are a great means of easily collecting data from a large number of samples cost effectively [17], a questionnaire with 30 questions covering participants' demographics, social factors, consumption habits, lifestyle habits, occupational habits, medical history and family information was developed after studying previously published researches related to my study. The questionnaire was administered in local languages to the participants and predominantly covering the Sinhala community. The questionnaires were checked and translated by professionals from the healthcare industry in order to ensure that most accurate findings can be captured using my study to evaluate the impact. As of its findings more males were affected than females and in approximately $2: 1$ ratio (Figure 6). A similar result which is a ratio of 2.6:1 and 2.4:1 for male: female in NCP and when considering all the nine provinces of the country together, respectively, has been obtained in a study carried out 


\section{Chart of Mean( Serum Creatinine Level $(\mathrm{mg} / \mathrm{dL})$ )}

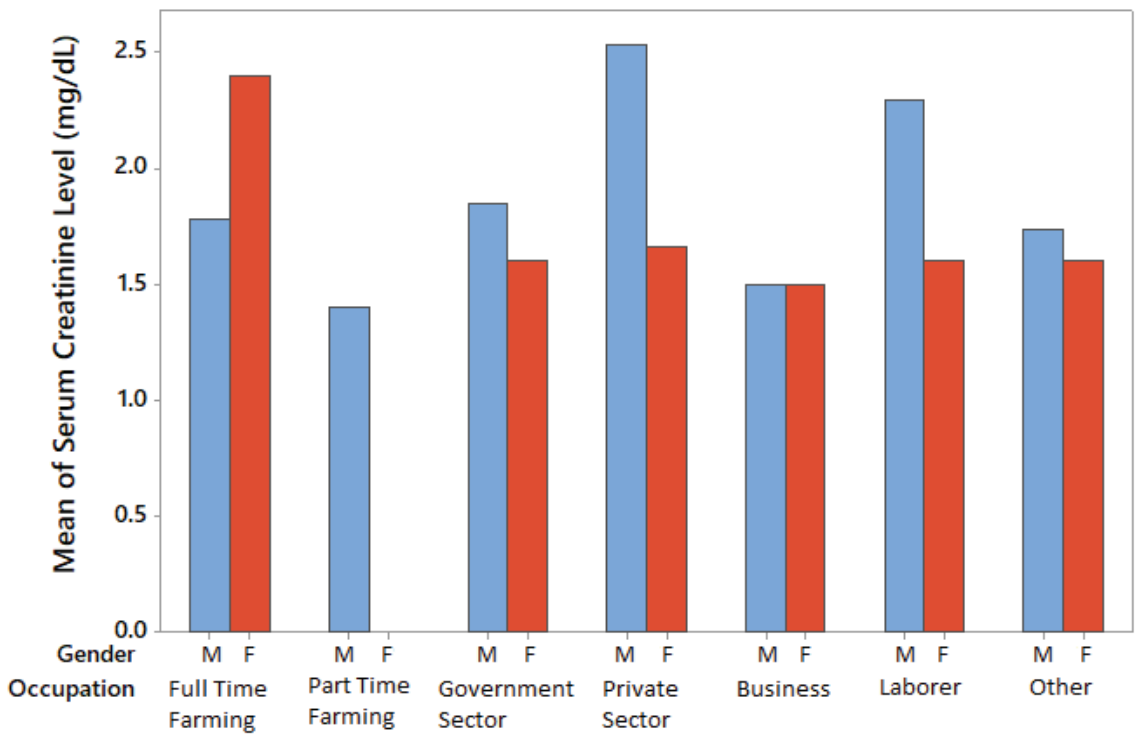

Figure 14: Variation of mean serum creatinine level with gender and occupation.

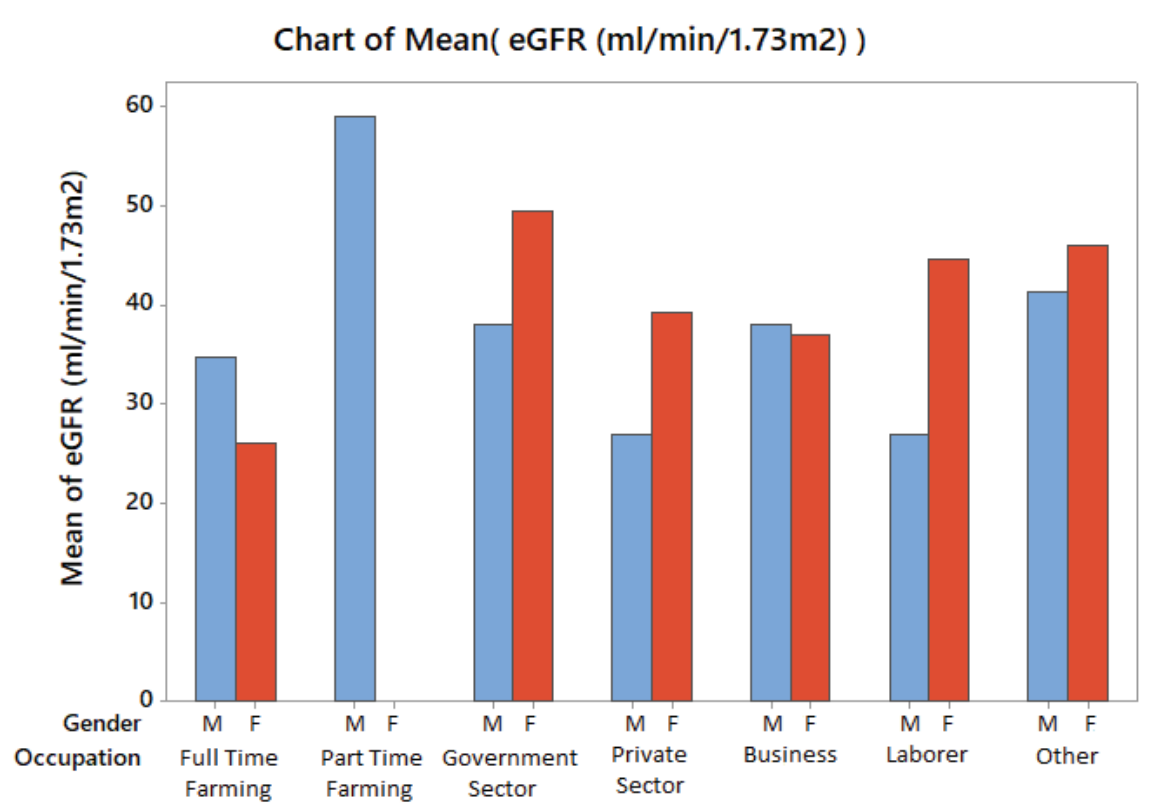

Figure 15: Variation of mean eGFR with gender and occupation.

in 2009-2011 period [25]. A study done in Leon, Nicaragua has also obtained the same ratio [26]. 56.67\% of patients participated in my study were aged 40-60yrs (Table 1). Similarly, the disease was seen to be high in this same age range in the study done in Nicaragua [26]. Since, heat stress is a hypothesized causative of CKDu, number of hours an individual get exposed to heat/sun was also assessed (Table 11). According to the study findings $96.67 \%$ of cases and $93.33 \%$ of controls were getting exposed to heat/sun daily for a period of 10 hours while the rest were getting exposed for more hours, showing only a $3.34 \%$ difference in heat/sun exposure between cases and controls. Therefore, further studies will be needed to confirm the impact of heat/sun exposure on CKDu occurrence taking facts like number of exposure hours, protective measures used against sunlight into consideration. Though studies have been previously carried out on this aspect, there's no significant evidence found up to now to say that CKDu in Sri Lanka is induced by heat stress but it has been identified as the main cause of MEN by a study in 2015 [9]. Another factor which goes hand in hand with heat stress is dehydration. 


\section{Scatterplot of Serum Creatinine Level (mg/dL) vs Body Mass Index_1}

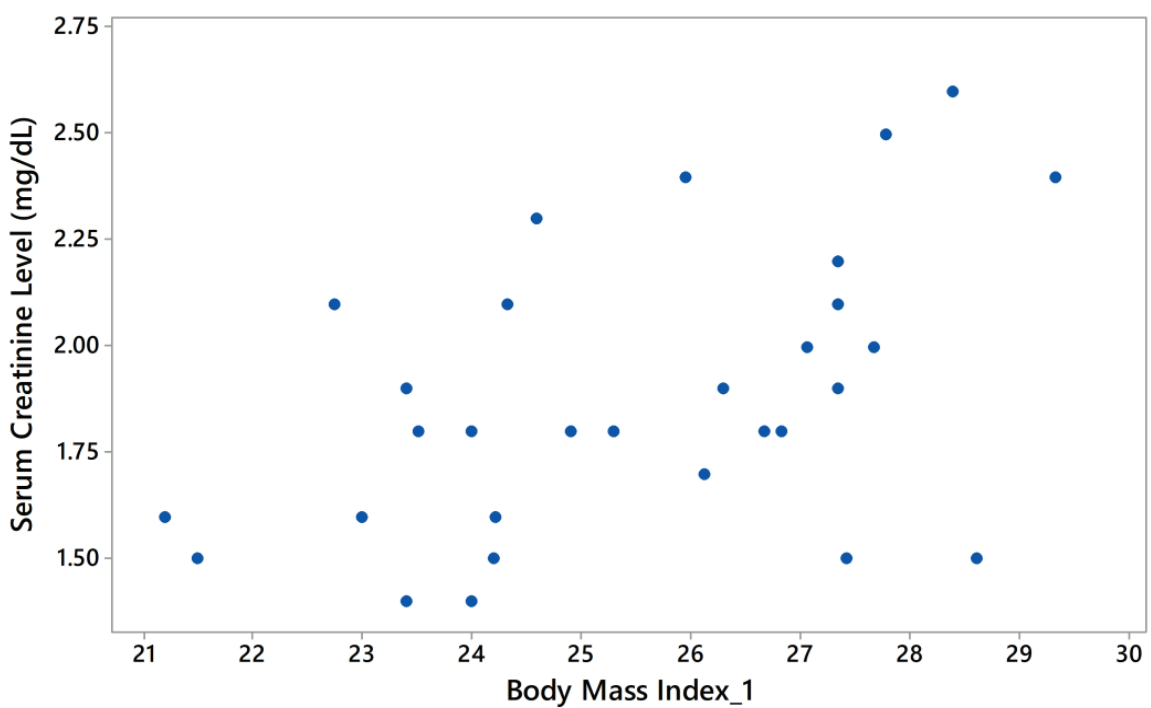

Figure 16: Relationship between BMI and serum creatinine.

Fitted Line Plot

Serum Creatinine Level $(\mathrm{mg} / \mathrm{dL})=-0.0165+0.07455$ Body Mass Index

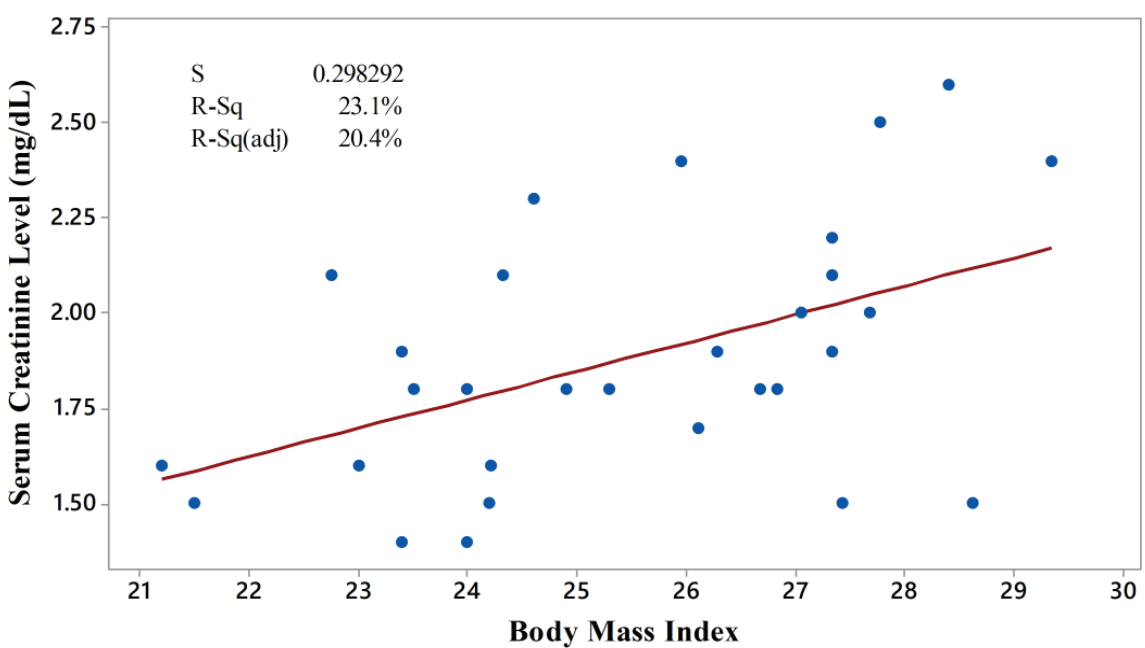

Figure 17: Relationship between BMI and serum creatinine with the line of best fit.

Therefore amount of water intake per day was examined in this study (Table 13 ) and found out that only a minority $(36.67 \%)$ of the cases drink more than $3 \mathrm{~L}$ of water per day where as more controls drink more than $3 \mathrm{~L}$ of water/day. But according to the guideline recommendations of WHO in 2004 for quality of drinking-water, there should be a minimum of 4-6 $\mathrm{L}$ of fluid replacement per day for a $70 \mathrm{~kg}$ individual living in the tropical zone and a fluid intake of $3.5 \mathrm{~L}$ or more per day for a person to be protected from CKD. This shows that the study patients have not consumed at least the minimum required amount of fluid needed per day to be protected from CKD and might have been suffering from dehydration from a longer time. Similarly, a study done in Madawachchiya in 2015 have found out that a significantly higher $(\mathrm{p}=0.003)$ percentages of diseased individuals work under sun for more than $6 \mathrm{hrs} /$ day consuming less than $3 \mathrm{~L}$ of water/day and that the probability of developing CKDu under such conditions is 8 times higher [10]. The serum creatinne levels analyzed using the blood samples collected from patients ranged from 1.3-2.8 $\mathrm{mg} / \mathrm{dL}$ with a mean of $1.8067 \mathrm{mg} / \mathrm{dL}$ and it was used in calculating their eGFRs in order to determine their CKDu stage (Figure 13). It was found that most $(73.3 \%)$ were in stage- 3 while $20 \%$ and $6.7 \%$ were in stages 4 and 2 respectively where no patients were found to be in stages 1 or 5 . As stated by a previous study, stage 3 is the most frequent stage present among the NCP residents where they have found males versus females in stage 3 is $23.2 \%$ versus $7.4 \%$ and those in stage 4 is $22 \%$ 


\section{Interval Plot of Serum Creatinine Level (mg/dL) vs No. of Hours Working Per Day_1}

\section{$95 \% \mathrm{Cl}$ for the Mean}

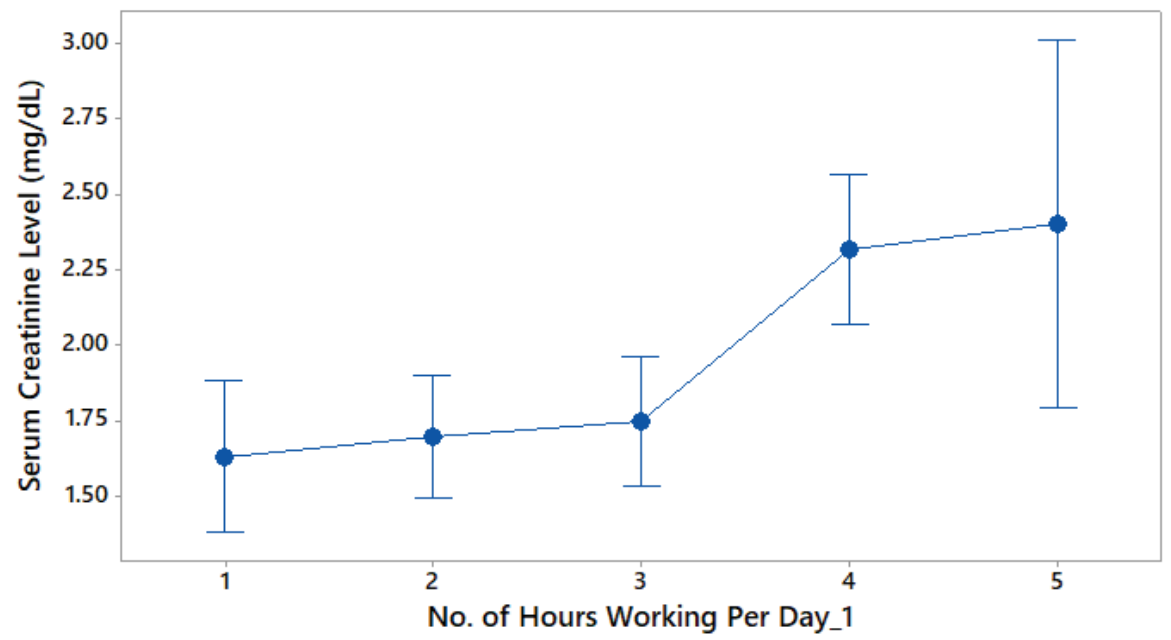

The pooled standard deviation was used to calculate the intervals.

Figure 18: One-way ANOVA: Serum Creatinine Level $(\mathrm{mg} / \mathrm{dL})$ versus number of hours working per day_1.

versus $7.3 \%$ with $\mathrm{P}<0.001$ [27]. When the average serum creatinine levels found from the study were compared gender wise (Table 15) it was observed that the value is relatively lower in females at $1.675 \mathrm{mg} /$ $\mathrm{dL}$ and higher in males at $1.8944 \mathrm{mg} / \mathrm{dL}$ which is mainly due to the sample size where male and female populations where $70 \%$ and $30 \%$ respectively. A recent study completed by Ranasinghe A, et al. also suggested that the average serum creatinine levels lie within the same boundary as my study [25]. Age has a significant relationship with the average serum creatinine levels where, the age group between 31-40 yrs and 41-50 yrs seems to show an overall increase in serum creatinine above $50 \%$ (Table 16) from the normal reference range of $0.7-1.2 \mathrm{mg} /$ dL. Moreover, several studies have highlighted the fact that this age group is more prone to have high levels of creatinine due to their intense hard work carried out at farms [28]. As for the study findings, farming members and laborers as expected showed the highest average of serum creatinine levels (Table 17) present this supports my study objective where occupation has a significant role to play in occurrence of $\mathrm{CKDu}$. These people have high muscle breakdown hence resulting in increased serum creatinine levels present in the body [29,30]. Two significant variables of gender and occupation data obtained from the study were compared against serum creatinine and eGFR levels (Figures 14 and 15). On average, farming community showed the highest difference between genders with females having a significantly higher average value of $2.4 \mathrm{mg} / \mathrm{dL}$ compared to males $1.8 \mathrm{mg} / \mathrm{dL}$, which is mainly due to the fact that sample size for the female farming population in the study was relatively lower than males. Number of working hours per day showed the highest significant relationship with serum creatinine out of the 8 other main questionnaire variables' correlation calculated using Cramer's V square test (Table 18). Therefore it was compared using logistic regression (Table 19) where each set contains a constant and coefficients for working per day, which is a categorical predictor. For logit 1 and 2, p- values are not less than the significance level of 0.10 . These results indicate that there is not enough evidence to conclude that a change in working hours effect on the patient's CKDu stage. Similarly, from other variables also do not have a significant nominal logistic regression. Then it was tested for terms with more than one degree of freedom where Chi-Square of 3.67943 and 0.00 with P-values of 0.451 and 1.00 where obtained for Logits 1 and 2 respectively. According to the ANOVA test which gave a P-value of 0.001 (Table 21\&22), (Supp table 1), alternative hypothesis is accepted where the average serum creatinine levels vary between working hours and showed a clear positive There is a clear positive relationship between working hours and serum creatinine levels (Figure 18), the higher the working hours the higher the serum creatinine levels go. As the p-value is $<0.05$, a statistically significant positive relationship between serum creatinine and BMI was observed. A regression model was developed for serum creatinine and BMI where it had a Pearson R correlation of 0.481 with a $\mathrm{P}$ of 0.007 but as its R-squared value is $20.4 \%$ the model could not be defined as a good model.

A major controversy that the study came up with is that all the patients who participated in the survey were following Sri Lankan Ayurdevic medicines for a period of more than six months which might probably have made an influence to their health condition and usual day to day activities at that time, affecting the results obtained from the survey. The study could only be carried out for a period of three months with a small sample size, while the collection of all socioeconomic and socio-demographic data was only done using an interview administered questionnaire without making any deep investigations into the participants' practical lifestyle and behaviours, which made the accuracy of the data collected to completely rely on participants' answers given which is definitely less reliable as individuals do not always intend to provide accurate and true information due to their privacy concerns. Also, only one biological parameter, serum creatinine was analyzed from which eGFR was calculated using CKDEPI equation which has no validity for Sri Lankans or South-Asians. These were limitations of the study to find out what the actual cause might have been in their lives for them to develop CKDu, the actual risk factors they were facing in their lives at the time of the study which was causing their state of disease and what the actual effect of all those factors on their serum creatinine levels. 
Yet the study has been successfully able to identify several social and occupational risk factors associated with CKDu in Kebithigollewa where age and number of working hours per day respectively being the main out of those as discussed above, with the presence of several strengths including its easiness and simplicity to apply, involvement and comparison with controls from same area as cases high (92.3\%) response rate of study participants, and the use of both internationally and locally accepted clinical and laboratory reference criteria.

This study could be further modified with considering each risk factor more in deep, investigating their actual life behaviours and getting involved a larger sample size comparing more of their clinical and biological parameters except the just serum creatinine levels.

\section{Conclusion}

The study findings indicate that the serum creatinine levels were high in farmers and laborers indicating that occupation has a significant role in the progression of CKDu in NCP. Number of working hours and BMI show a statistically significant relationship between the two factors with a $\mathrm{p}$ value of $<0.05$ obtained. The preliminary findings of the study does indicate the link between occupation progression of CKDu but further studies needs to be conducted to ensure that this hypothesis can be proved.

\section{Acknowledgement}

I wish to acknowledge the British College of Applied Studies, Sri Lanka and University of Wolverhampton, United Kingdom for paving me the path to carry out this project. Next, I wish to express my heartfelt gratitude to my supervisor Dr. Nishantha Kumarasinghe and co-supervisors Mr. Fahim Aslam and Dr. Vindika Suriyakumara who have always been helping and guiding me to achieve the goal of my research. Also, I would like to give forth my sincere appreciation to my project coordinator Ms. Surangi Fernando for all the advices and directions given from the beginning. At last but not the least, I wish to thank all the participants of my research and all others who have been supporting me to make my study a success.

\section{Conflict of Interest}

None.

\section{References}

1. Ruwanpathirana T, Senanayake S, Gunawardana N, Munasinghe A, Ginige S, et al. (2019) Prevalence and risk factors for impaired kidney function in the district of Anuradhapura, Sri Lanka: a cross-sectional population-representative survey in those at risk of chronic kidney disease of unknown aetiology. BMC Public Health 19: 763.

2. Pry J, Jackson W, Rupasinghe R, Lishanthe G, Badurdeen Z, et al. (2019) A pilot study of behavioral, environmental, and occupational risk factors for chronic kidney disease of unknown etiology in Sri Lanka.

3. Wanigasuriya K (2012) Aetiological factors of Chronic Kidney Disease in the North Central Province of Sri Lanka: A review of evidence todate. Journal of the College of Community Physicians of Sri Lanka 17: 15-20.

4. Gunatilake SK, Samaratunga SS, Rubasinghe RT (2015) Chronic Kidney Disease (CKD) in Sri Lanka - Current Research Evidence Justification: A Review. Sabaragamuwa University J 13: 31-58.

5. Wijewickrama ES, Gunawardena N, Jayasinghe S, Herath C (2019) CKD of Unknown Etiology (CKDu) in Sri Lanka: A Multilevel Clinical Case Definition for Surveillance and Epidemiological Studies. Kidney Int Rep 4: 781-785.
6. Gifford FJ, Gifford RM, Eddleston M, Dhaun N (2017) Endemic Nephropathy around the World. Kidney Int Rep 2: 282-292.

7. Johnson RJ, Wesseling C, Newman LS (2019) Chronic Kidney Disease of Unknown Cause in Agricultural Communities. N Engl J Med 380: 1843-1852.

8. Rajapakse S, Shivanthan M, Selvarajah M (2016) Chronic kidney disease of unknown etiology in Sri Lanka. Int J Occup Environ Health 22: 259-264.

9. Aslam F (2020) Risk Factors Associated with Chronic Kidney Disease of Unknown Origin (Ckdu) in North Central Province (NCP) of Sri Lanka: An Analysis of Evidence to Date. J Med Case Rep Case Series 1.

10. Siriwardhana EARIE, Perera PAJ, Sivakanesan R, Abeysekara T, Nugegoda DB, et al. (2015) Dehydration and malaria augment the risk of developing chronic kidney disease in Sri Lanka. Indian J Nephrol 25: 146-151.

11. Wijkström J, Jayasumana C, Dassanayake R, Priyawardane N, Godakanda N, et al. (2018) Morphological and clinical findings in Sri Lankan patients with chronic kidney disease of unknown cause (CKDu): Similarities and differences with Mesoamerican Nephropathy. PLoS One 13: e0193056.

12. Chandrajith R, Nanayakkara S, Itai K, Aturaliya TNC, Dissanayake CB, et al. (2010) Chronic kidney diseases of uncertain etiology (CKDue) in Sri Lanka: geographic distribution and environmental implications. Environ Geochem Health 33: 267-278.

13. Kumarasinghe $N$, Suriyakumara V, Aslam F, Hakmanage NM, Galgamuwa L, et al. (2019) Follow up Study on Sri Lankan Traditional Medicine Treatment on Diagnosed Chronic Kidney Disease of Unknown Etiology Patients in Kebithigollewa, North Central Province (NCP), Sri Lanka. J Kidney 5: 175.

14. Sayanthooran S, Magana-Arachchi DN, Gunerathne L, Abeysekera T (2017) Potential diagnostic biomarkers for chronic kidney disease of unknown etiology (CKDu) in Sri Lanka: a pilot study. BMC Nephrol 18: 31.

15. Devarajan P (2008) Neutrophil gelatinase-associated lipocalin (NGAL): a new marker of kidney disease. Scand J Clin Lab Invest Suppl 241: 89-94.

16. Taherkhani A, Yekta RF, Mohseni M, Saidijam M, Oskouie AA (2019) Chronic kidney disease: a review of proteomic and metabolomic approaches to membranous glomerulonephritis, focal segmental glomerulosclerosis, and IgA nephropathy biomarkers. Proteome Sci 17: 7.

17. Jones TL, Baxter MAJ, Khanduja V (2013) A quick guide to survey research. Ann R Coll Surg Engl 95: 5-7.

18. Cohen DE, Lee A, Sibbel S, Benner D, Brunelli SM, et al. (2019) Use of the KDQOL- $36^{\mathrm{TM}}$ for assessment of health-related quality of life among dialysis patients in the United States. BMC Nephrol 20: 112.

19. Elledge ME, Redmon JH, Levine KE, Wickremasinghe RJ, Wanigasariya KP, et al. (2014) Chronic kidney disease of unknown etiology in Sri Lanka: Quest for understanding and global implications. RTI Press.

20. Premadasa HKS, Priyanath HMS, Walpita CN (2020) The Impact of Social Capital on Socioeconomic Condition of Ckdu Patients in Sri Lanka: An Empirical Investigation. Int J Sci Res Manag 8: 377-388.

21. Jayasumana MACS, Paranagama PA, Amarasinghe MD, Wijewardane KMRC, Dahanayake KS, et al. (2013) Possible link of Chronic arsenic toxicity with Chronic Kidney Disease of unknown etiology in Sri Lanka. J Nat Sci Res 3: 64-73. 
22. Mangala P, De Silva CS (2014) Chronic kidney disease of unknown etiology: Mystery unsolved. Journal of the University of Ruhuna 2 1-3.

23. Bandarage A (2013) Political Economy of Epidemic Kidney Disease in Sri Lanka. SAGE Open 3: 1-13.

24. O'Callaghan-Gordo C, Shivashankar R, Anand S, Ghosh S, Glaser J, et al. (2019) Prevalence of and risk factors for chronic kidney disease of unknown aetiology in India: secondary data analysis of three population-based cross- sectional studies. BMJ Open 9: e023353.

25. Jayasekara KB, Dissanayake DM, Sivakanesan R, Ranasinghe A, Karunarathna $\mathrm{RH}$, et al. (2015) Epidemiology of chronic kidney disease, with special emphasis on chronic kidney disease of uncertain etiology, in the north central region of Sri Lanka. J Epidemiol 25: 275-280.

26. Lebov JF, Valladares E, Peña R, Peña EM, Sanoff SL, et al. (2015) A Population-Based Study of Prevalence and Risk Factors of Chronic Kidney Disease in León, Nicaragua. Can J Kidney Health Dis 2: 6.
27. Jayatilake $\mathrm{N}$, Mendis $\mathrm{S}$, Maheepala $\mathrm{P}$, Mehta FR, CKDu National Research Project Team (2013) Chronic kidney disease of uncertain aetiology: prevalence and causative factors in a developing country. BMC Nephrol 14: 180.

28. Weaver VM, Fadrowski J, Jaar BG (2015) Global dimensions of chronic kidney disease of unknown etiology (CKDu): a modern era environmental and/or occupational nephropathy? BMC Nephrol 16: 145.

29. Abeyagunawardena AS, Shroff R (2020) CKDu: the known unknowns Pediatr Nephrol 36: 219-221.

30. Dissanayake CB, Chandrajith R (2017) Groundwater fluoride as a geochemical marker in the etiology of chronic kidney disease of unknown origin in Sri Lanka. Ceylon Journal of Science 46: 3-12.

Supplementary Table 1: Important data collected from participants.

\begin{tabular}{|c|c|c|c|c|c|c|c|}
\hline Age (Years) & Gender & $\begin{array}{l}\text { Body Mass Index } \\
\qquad\left(\mathrm{kg} / \mathrm{m}^{2}\right)\end{array}$ & $\begin{array}{l}\text { Serum Creatinine } \\
\text { Level }(\mathrm{mg} / \mathrm{dL})\end{array}$ & Age (Years) & Gender & $\begin{array}{l}\text { Body Mass Index } \\
\qquad\left(\mathrm{kg} / \mathrm{m}^{2}\right)\end{array}$ & $\begin{array}{l}\text { Serum Creatinine } \\
\text { Level (mg/dL) }\end{array}$ \\
\hline 62 & Female & 25.95 & 1.3 & 25 & Female & 23.7 & 0.8 \\
\hline 70 & Male & 26.29 & 1.9 & 37 & Male & 46.4 & 0.9 \\
\hline 49 & Male & 27.78 & 1.8 & 25 & Female & 20.6 & 0.8 \\
\hline 73 & Male & 26.83 & 2.3 & 53 & Male & 17.7 & 1.1 \\
\hline 60 & Male & 26.7 & 1.8 & 55 & Male & 23.8 & 1.0 \\
\hline 64 & Female & 28.62 & 1.5 & 56 & Female & 33.9 & 0.6 \\
\hline 71 & Male & 23.51 & 1.8 & 20 & Male & 16 & 0.9 \\
\hline 58 & Male & 24.22 & 1.6 & 58 & Male & 19.5 & 1.2 \\
\hline 62 & Male & 27.43 & 1.5 & 22 & Male & 19.6 & 0.9 \\
\hline 55 & Male & 26.67 & 1.8 & 38 & Male & 24.2 & 1.0 \\
\hline 44 & Female & 27.06 & 2.3 & 60 & Male & 23 & 1.1 \\
\hline 47 & Male & 23.4 & 1.4 & 60 & Female & 25 & 0.7 \\
\hline 73 & Female & 27.34 & 1.5 & 63 & Male & 32.1 & 1.1 \\
\hline 65 & Male & 24 & 1.4 & 61 & Female & 35.1 & 0.9 \\
\hline 45 & Female & 23.4 & 1.9 & 50 & Female & 16.3 & 0.7 \\
\hline 53 & Male & 26.12 & 1.7 & 74 & Female & 18 & 1.0 \\
\hline 53 & Female & 22.1 & 1.6 & 72 & Female & 23.7 & 0.9 \\
\hline 49 & Male & 27.68 & 1.4 & 50 & Male & 24.3 & 1.0 \\
\hline 60 & Male & 20.6 & 1.8 & 35 & Female & 22.4 & 0.7 \\
\hline 73 & Female & 29.34 & 2.1 & 61 & Male & 24 & 0.9 \\
\hline 64 & Male & 27.34 & 2.2 & 40 & Male & 22 & 0.9 \\
\hline 58 & Female & 24.2 & 1.5 & 52 & Male & 24.1 & 1.0 \\
\hline 55 & Male & 22.6 & 1.5 & 32 & Female & 21.4 & 0.7 \\
\hline 63 & Male & 27.34 & 1.5 & 54 & Male & 20 & 1.1 \\
\hline 48 & Male & 24.8 & 2.6 & 30 & Male & 21.4 & 1.0 \\
\hline 58 & Male & 27.47 & 1.6 & 39 & Male & 23.3 & 1.1 \\
\hline 60 & Male & 27.47 & 1.8 & 47 & Female & 22.3 & 0.8 \\
\hline 67 & Male & 24.33 & 2.8 & 37 & Male & 22.8 & 0.9 \\
\hline 52 & Female & 28.13 & 1.9 & 48 & Male & 19.6 & 1.1 \\
\hline 74 & Male & 27.68 & 2.4 & 42 & Female & 18 & 0.9 \\
\hline
\end{tabular}




\section{Appendix}

Questionnaire developed for the survey:

\section{Identification of Social and Occupational Risk Factors associated with CKDu Patients in an} Agricultural Community in Kebithigollewa, Sri Lanka.

Patient Code:

Address:

Duration of Stay in North Central Region:

01. Age:

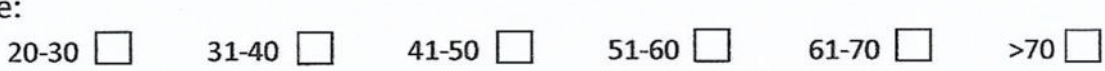

02. Gender: Male $\square \quad$ Female $\square$

03. Body Mass Index $\left(\mathrm{kg} / \mathrm{m}^{2}\right)$ : Underweight ( $\leq 18.5) \quad \square \quad$ Normal $(>18.5-\leq 25) \square \quad \square \quad$ Overweight $(>25-\leq 30) \square \quad \square \quad$ Obese (>30)

04. Ethnicity Sinhalese $\square \quad$ Tamil $\square \quad$ Muslim $\square \quad$ Other

05. No of Years Suffering with the Disease
$<1 \square$
1-5
5-10
$>10$
Not Affected

06. Other Diseases Diagnosed

Diabetes $\square \quad$ High Blood Pressure $\square \quad$ Wheeze $\square \quad$ None $\square \quad$ Other

07. Level of Stress

None $\square \quad$ Little $\square \quad$ Moderate $\square \quad$ High $\square$

08. Occupation

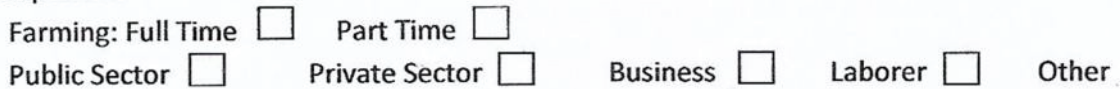

09. No. of Hours Working Per Day
1-4 $\square \quad 4-8$
8-11
$>11$
Other

10. Monthly Income (Rs.)

$\begin{array}{lll}1,500-10,000 \square & \begin{array}{l}10,000-20,000 \\ 40,000-50,000\end{array} \quad \begin{array}{l}20,000-30,000 \\ 50,000-100,000\end{array} \quad \begin{array}{l}300,000 \\ 4\end{array} \quad \begin{array}{l}30,000-40,000 \\ \text { No Income }\end{array}\end{array}$

11. Duration of Heat/ Sun Exposure: $<10 \mathrm{hrs} \square \quad>10 \mathrm{hrs} \square \quad$, Other:

12. Exposure to Agrochemicals

None $\square \quad$ Little $\square \quad$ Moderate $\square \quad$ High

13. Duration of Use of Agrochemicals: per Year

14. Use of Protection when Handling Agrochemicals Always $\square \quad$ Sometimes $\square \quad$ Never $\square \quad$ Protection Used: Gloves/ Boots/ masks/ other...........

15. Level of Education (Grade)
$<5 \square$
5-10
$\mathrm{O} / \mathrm{L}$
$A / L$
Graduate
None
Other

16. No. of Hours Sleeping Per Day

$<6 \quad 6-8 \square \quad>8 \square \quad$ Other 
17. Level of Social Interactions

None $\square \quad$ Little $\square \quad$ Moderate $\square \quad$ High $\square$

18. Source of Water

Well $\square$ Tube Well $\square \quad$ Rain Water Repository $\square \quad$ Natural Springs $\square \quad$ Filtered Water $\square$

Other

19. Amount of Water Intake per day: $<3 L \square>3 L$

20. Dietary Habits

Vegetarian $\square \quad$ Non Vegetarian $\square \quad$ Other

21. Consumption of Tobacco/ Alcohol/ Betle

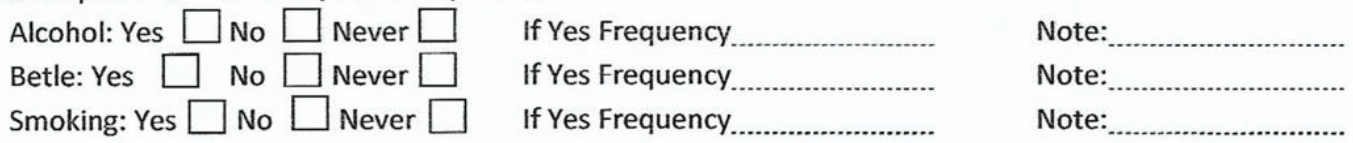

22. Exercising: Yes $\square \quad$ No $\square \quad$ Sometimes

23. Engagement in Physical Activities

Inactive $\square \quad$ Moderate $\square \quad$ Active

24. Civil Status

Single $\square \quad$ Married $\square \quad$ Other

25. No. of Members in the Household
1-2 $\square$
3-5
6-8
$>8$

26. Level of Education of the Member with the Highest Educational Qualification (Grade)
$<5 \square$
5-10
$\mathrm{O} / \mathrm{L}$
A/L
Graduate $\square \quad$ None
Other

27. No. of Members Working in the Family
1
3
$>3$
None

28. Occupations of the Members of Household Student $\square \quad$ Farming: Full Time $\square \quad$ Part Time

Public Sector $\square \quad$ Private Sector $\square \quad$ Business $\square \quad$ Laborer $\square \quad$ Other

29. Total monthly Income of the Family (Rs.)

$\begin{array}{lll}1,500-10,000 \square & \begin{array}{l}10,000-20,000 \\ 40,000-50,000\end{array} \quad \begin{array}{l}20,000-30,000 \\ 50,000-100,000\end{array} \quad \begin{array}{l}300,000 \\ 5\end{array} & \begin{array}{l}30,000-40,000 \\ \text { No Income }\end{array}\end{array}$

30. No. of CKDu Affected Members in the Family
1
2
$>3$
None
No. of Members Died due to CKDu 